\title{
Nongenomic Actions of 17- $\beta$ Estradiol Restore Respiratory Neuroplasticity in Young Ovariectomized Female Rats
}

\author{
Brendan J. Dougherty, Elizabeth S. Kopp, and Jyoti J. Watters \\ Department of Comparative Biosciences, School of Veterinary Medicine, University of Wisconsin-Madison, Madison, Wisconsin 53706
}

Gonadal steroids modulate CNS plasticity, including phrenic long-term facilitation (pLTF), a form of spinal respiratory neuroplasticity resulting in increased phrenic nerve motor output following exposure to acute intermittent hypoxia (aIH; three 5 min episodes, $10.5 \%$ $\mathrm{O}_{2}$ ). Despite the importance of respiratory system neuroplasticity, and its dependence on estrogen in males, little is known about pLTF expression or mechanisms of estrogen signaling in females. Here, we tested the hypotheses that (1) pLTF expression in young, gonadally intact female rats would be expressed during estrous cycle stages in which $17 \beta$-estradiol (E2) is naturally high (e.g., proestrus vs estrus), (2) pLTF would be absent in ovariectomized (OVX) rats and in physiological conditions in which serum progesterone, but not E2, is elevated (e.g., lactating rats, 3-10 d postpartum), and (3) acute E2 administration would be sufficient to restore pLTF in OVX rats. Recordings of phrenic nerve activity in female Sprague Dawley rats (3-4 months) revealed a direct correlation between serum E2 levels and pLTF expression in cycling female rats. pLTF was abolished with OVX, but was re-established by acute E2 replacement $(3 \mathrm{~h}$, intraperitoneal). To identify underlying E2 signaling mechanisms, we intrathecally applied BSA-conjugated E2 over the spinal phrenic motor nucleus and found that pLTF expression was restored within $15 \mathrm{~min}$, suggesting nongenomic E2 effects at membrane estrogen receptors. These data are the first to investigate the role of ovarian E2 in young cycling females, and to identify a role for nongenomic estrogen signaling in any form of respiratory system neuroplasticity.

Key words: estradiol; long-term facilitation; phrenic; plasticity

\section{Significance Statement}

Exposure to acute intermittent hypoxia induces phrenic long-term facilitation (pLTF), a form of spinal respiratory motor plasticity that improves breathing in models of spinal cord injury. Although pathways leading to pLTF are well studied in males and estradiol (E2) is known to be required, it has seldom been investigated in females, and underlying mechanisms of E2 signaling are unknown in either sex. We found that while ovariectomy abolished PLTF, it could be restored by acute systemic E2, or by intraspinal application of the membrane-impermeable E2 (BSA-conjugated E2; $15 \mathrm{~min}$ ). The ability of nongenomic estrogen signaling within the cervical spinal cord to recover respiratory neuroplasticity in disorders of respiratory insufficiency suggests that membrane estrogen receptors may represent novel therapeutic targets to restore breathing in both sexes.

\section{Introduction}

Cyclic fluctuations in circulating $17 \beta$-estradiol (E2) regulate CNS plasticity in female rats (Bi et al., 2001). Indeed, gonadal steroid signaling in neuroplasticity is well established in rodent models of learning and memory (Smith et al., 2009; Baudry et al.,

\footnotetext{
Received Feb. 15, 2017; revised April 18, 2017; accepted May 5, 2017.

Author contributions: B.J.D. and J.J.W. designed research; B.J.D. and E.S.K. performed research; J.J.W. contributed unpublished reagents/analytic tools; B.J.D., E.S.K., and J.J.W. analyzed data; B.J.D. and J.J.W. wrote the paper.

This work was supported by grants from the National Institute of Health (R01 HL111598 and R01 NS085226;

J.J.W.) and an award from the Vilas Family Foundation.

The authors declare no competing financial interests.

Correspondence should be addressed to Jyoti J. Watters, PhD, 2015 Linden Drive, Madison, WI 53706. E-mail: jiwatters@wisc.edu.

DOI:10.1523/JNEUROSCI.0433-17.2017

Copyright $\odot 2017$ the authors $\quad 0270-6474 / 17 / 376648-13 \$ 15.00 / 0$
}

2013; Arevalo et al., 2015; Fester and Rune, 2015; Frick, 2015). Hippocampal long-term potentiation (LTP) is greater in slices prepared from female rats in proestrus (characterized by high circulating E2 levels) versus diestrus (low circulating E2; Bi et al., 2001; Baudry et al., 2013), and exogenous E2 restores LTP in ovariectomized (OVX) rats (Córdoba Montoya and Carrer, 1997), supporting a critical role for E2 in hippocampal neuroplasticity (Frick, 2015).

The spinal respiratory motor system also possesses the robust capacity to exhibit neuroplasticity. Phrenic long-term facilitation (pLTF; Hayashi et al., 1993; Bach and Mitchell, 1996), a form of neuroplasticity induced by acute, intermittent hypoxia $(\mathrm{aIH}$; Bach and Mitchell, 1996; Baker and Mitchell, 2000), is characterized by a progressive and long-lasting increase in phrenic motor neuron output. It has been extensively characterized, and now 
guides preclinical trials in chronic spinal cord injury patients to improve their motor function (Trumbower et al., 2012; Hayes et al., 2014; Navarrete-Opazo et al., 2016, 2017; Lynch et al., 2017). While pLTF in young castrated male rats requires the conversion of testosterone to E2 (Zabka et al., 2006), reports conflict regarding the existence of pLTF in young females in estrus and diestrus (Zabka et al., 2001, 2006). We hypothesized that pLTF would be expressed in young female rats during estrous cycle stages characterized by high circulating E2 levels (i.e., proestrus vs estrus). We predicted that pLTF would be abolished by OVX and physiological conditions in which progesterone, but not E2, was elevated (e.g., postpartum lactating rats; Grota and Eik-Nes, 1967). Further, we predicted that E2 replacement would restore pLTF in OVX rats. We also tested whether a membrane-active E2 (intraspinal) could mimic systemic E2 effects. Our results demonstrate that rapid estrogen signaling plays a critical role in pLTF. Thus, membrane estrogen receptors (ERs) may be an important translational consideration for promoting spinal neuroplasticity in clinical conditions characterized by respiratory insufficiency (Dale et al., 2014; Navarrete-Opazo and Mitchell, 2014; Gonzalez-Rothi et al., 2015; Fuller and Mitchell, 2017).

\section{Materials and Methods}

Animals. Adult, female Sprague Dawley rats (3-4 months old) were housed in an Association for Assessment and Accreditation of Laboratory Animal Care-accredited animal facility with ad libitum access to food and water and $12 \mathrm{~h}$ light/dark cycles. All experimental procedures were approved by the Animal Care and Use Committee at the University of Wisconsin-Madison and conformed to policies set out by the National Institutes of Health Guide for the Care and Use of Laboratory Animals.

For the first set of experiments, 45 virgin or postpartum rats were divided into the following six groups: (1) ovarian-intact females in estrus $(n=8)$; (2) ovarian-intact females in proestrus $(n=8)$; (3) OVX females $(n=8)$; (4) OVX females receiving estrogen supplementation $(n=8)$; (5) lactating, postpartum females $(n=8)$; and (6) time controls consisting of one rat from each of the previous five groups $(n=5)$. Rats that had undergone a minimum of one full estrous cycle following arrival were assigned to either the estrus or proestrus groups based on daily examination of vaginal cell characteristics in vaginal smears using light microscopy (Marcondes et al., 2002). The lactating females were within 3-10 d postpartum, and had litters of $\geq 4$ pups at the time of experimentation. In subsequent experiments, 16 virgin OVX rats were divided into the following three groups: (1) intrathecal BSA-conjugated E2 (E2-BSA; $n=5)$; (2) intrathecal BSA alone $(n=5)$; and (3) time controls consisting of three rats from each of these groups $(n=6)$.

Preparation of E2-BSA. The E2-BSA (30 moles E2 per moles BSA) solution was reconstituted in PBS, and free E2 was removed based on weight as previously described (Stevis et al., 1999), using $3 \mathrm{kDa}$ molecular weight centrifugal filters (Amicon Ultra-15, Millipore). The larger molecularweight E2-BSA is trapped on the filter. Retained E2-BSA was reconstituted in aCSF (0.5 mM stock; Nag and Mokha, 2014) and spectrophotometry was used to confirm the molarity of both the BSA-conjugated and free E2 fractions ( $<1 \%$ of free E2 contamination was found in the E2-BSA lots used in these studies). BSA at equimolar concentrations to that injected in the conjugated E2-BSA was delivered to rats in the control group.

Ovariectomy. Ovariectomy was performed as previously described (Zhou et al., 1996). Briefly, rats were initially anesthetized with isoflurane in a closed chamber and then maintained via nose cone $\left(2-3 \%\right.$ in $\left.\mathrm{O}_{2}\right)$ for the duration of surgery. Adequacy of anesthesia was confirmed by the lack of response to toe-pinch and by eye-blink reflexes. Bilateral incisions were made through the dorsolateral skin and muscle layers to expose the ovarian fat pads. Following bilateral removal of ovaries, muscle layers were approximated, and the skin incision was closed with wound clips (Appose ULC 35W, Covidien); buprenorphine was administered for pain control $\left(0.05 \mathrm{~g} \times \mathrm{kg}^{-1}\right.$, s.c. $)$. Rats recovered in their home cages for $\geq 1$ week before phrenic neurophysiological experiments. The ovarian fat pads were briefly exteriorized in rats receiving sham ovariectomy; they underwent the same recovery procedures. Daily vaginal smears commenced on the sham rats 1 week after surgery, and rats were assigned to the appropriate estrous cycle group based on vaginal cell characteristics, as in the intact female groups. All smears were performed at the same time of day, and all nerve recordings were performed immediately after vaginal cell analysis.

Surgical preparation for electrophysiological measurements. Rats were anesthetized initially with isoflurane in a closed chamber, then transferred to a nose cone for tracheotomy and initiation of pump ventilation (Rodent Ventilator, model 683, Harvard Apparatus; tidal volume, 1.5$2.5 \mathrm{ml}$; frequency, 75 breaths $\times \mathrm{min}^{-1}$ ). Tracheal pressure was continuously monitored using a pressure transducer (model MLT1199, AD Instruments) attached to the inspired line of the ventilator. The lungs were briefly hyperinflated by occluding the expiratory line of the ventilator once per hour to minimize atelectasis (collapse of lung alveoli resulting in decreased blood oxygenation). Anesthesia was maintained with isoflurane $\left(3 \%\right.$ in $50 \% \mathrm{O}_{2}$, balance $\mathrm{N}_{2}$ ) for the duration of the surgical procedures and adequacy of isoflurane anesthesia was confirmed by the lack of response to toe-pinch and eye-blink reflexes.

Following surgery, rats were slowly converted to urethane anesthesia $\left(1.8 \mathrm{mg} \times \mathrm{kg}^{-1}\right)$ via right femoral vein catheter. Surgery was performed on a temperature-controlled stainless-steel surgical table. Rectal temperature was monitored continuously with a temperature sensor (Physitemp Instruments), and maintained constant by adjusting the temperature of the surgical table. The concentration of inspired $\mathrm{O}_{2}$ was monitored throughout all experiments using a fuel-cell $\mathrm{O}_{2}$ sensor (AII 3000A, Analytical Industries). Rats were vagotomized and a catheter was inserted into the right femoral artery to monitor blood pressure using a calibrated pressure transducer (SP844, MEMScap). Blood samples drawn from the femoral artery were analyzed for $\mathrm{O}_{2}\left(\mathrm{PaO}_{2}\right)$ and $\mathrm{CO}_{2}\left(\mathrm{PaCO}_{2}\right)$ partial pressures and $\mathrm{pH}$ with a blood gas analyzer (ABL800 Flex, Radiometer); standard base excess (SBE), calculated by the analyzer, was also used as an indicator of metabolic acidbase disturbances. A slow, continuous infusion of veterinary lactated Ringer's solution, hetastarch, and sodium bicarbonate via femoral vein catheter was maintained following conversion to urethane anesthesia to maintain blood pressure and acid-base balance throughout the experiment. The left phrenic nerve was dissected, exposed via a dorsal approach, cut distally, and then desheathed. The nerve was submerged in mineral oil and placed on a bipolar silver recording electrode to record spontaneous neural activity. The adequacy of anesthesia was tested before protocols commenced and immediately after the protocol was complete. Adequacy of anesthetic depth was assessed as the lack of pressor or respiratory neural response to a toe pinch. We did not observe increased blood pressure or respiratory nerve activity in any of the rats following toe pinch. Neuromuscular blockade with pancuronium bromide $\left(\sim 1.2 \mathrm{ml}\right.$, i.v., $\left.1 \mathrm{mg} \times \mathrm{ml}^{-1}\right)$ was initiated following confirmation of adequate anesthesia to remove excessive movement artifacts associated with respiratory muscle activity. End-tidal $\mathrm{CO}_{2}$ was monitored using a flow-through capnograph (Novametrix) and maintained at $\sim 45$ $\mathrm{mmHg}$ throughout the surgery to allow stabilization of the preparation and initial nerve signals.

Rats receiving intraperitoneal E2 replacement following ovariectomy were given a single dose of estradiol benzoate $\left(40 \mu \mathrm{g} \times \mathrm{kg}^{-1}\right.$; i.p. $) \sim 3 \mathrm{~h}$ before the start of hypoxic challenges with the goal of approximating serum levels of estradiol measured during the proestrus phase in this rat strain. Nerve activity was amplified (gain, 10,000×; A-M systems), bandpass-filtered (300 Hz to $10 \mathrm{kHz}$ ), rectified, and integrated (time constant, $100 \mathrm{~ms}$ ). Resulting signals were digitized, recorded, and analyzed with PowerLab (AD Instruments; LabChart 7.0 software). For experiments assessing nongenomic E2 signaling, an intrathecal catheter was placed to enable localized injections of BSA or E2-BSA over the region of the phrenic motor nucleus. In brief, after dorsal laminectomy at $\mathrm{C} 2$, an incision was made in the dura and a small silicone catheter (2 French; Access Technologies) was inserted and advanced $\sim 3 \mathrm{~mm}$ caudally, bringing the catheter tip to the rostral edge of cervical segments containing the phrenic motor nucleus $(\sim \mathrm{C} 3)$. The catheter was primed with either E2-BSA [ $\beta$-estradiol 6-(O-carboxy-methyl) oxime:BSA, $50 \mathrm{~nm}$; Sigma-Aldrich] or vehicle (containing equivalent moles of BSA (1.5 nM) in aCSF; Jackson Immunoresearch) before 
catheter placement. Intrathecal solutions were prepared fresh for each experiment and intrathecal drug dosing was established following dose-response experiments.

Experimental protocol for electrophysiological measurements. Stable nerve activity was established while the rat was ventilated with a hyperoxic inspired gas mixture $\left(\mathrm{FIO}_{2}, 0.5-0.6 ; \mathrm{PaO}_{2},>250 \mathrm{mmHg}\right)$, with sufficient levels of inspired $\mathrm{CO}_{2}$ to maintain constant arterial $\mathrm{PaCO}_{2}$, preventing the rat from becoming apneic (typically between 40 and 45 $\mathrm{mmHg}$ ). After the preparation was stabilized, the apneic threshold for rhythmic phrenic activity was determined by progressively lowering the inspired (and arterial) $\mathrm{CO}_{2}$ until rhythmic phrenic activity ceased. From apnea, the end-tidal $\mathrm{CO}_{2}$ was progressively increased in $1 \mathrm{mmHg}$ increments every 1-2 min until nerve activity resumed (i.e., the recruitment threshold). Baseline nerve activity was established with end-tidal $\mathrm{CO}_{2}$ set 2-3 mmHg above the $\mathrm{CO}_{2}$ recruitment threshold. This procedure allows a standardized level of respiratory drive during baseline conditions in different rats. A baseline blood sample was taken and the rats were exposed to acute aIH, consisting of $3 \times 5$ min hypoxic episodes $\left(\mathrm{FIO}_{2}\right.$, $0.10-0.12 ; \mathrm{PaO}_{2}, 35-45 \mathrm{mmHg}$ ) interspersed with 5 min intervals of baseline conditions (i.e., $\mathrm{FIO}_{2}, 0.5-0.6$ ). Additional time-control rats were used to ensure stability of phrenic nerve recordings over time (i.e., ensuring that there was no time-dependent change in phrenic nerve output). These rats did not receive hypoxia, and were included to assess the effects on baseline nerve activity in OVX rats, in OVX rats pretreated with estradiol benzoate (EB; OVX+E), and in OVX rats pretreated with E2-BSA (OVX+E2-BSA) or BSA. For experiments assessing nongenomic E2 signaling, rats received an intrathecal injection of E2-BSA or BSA alone ( $12 \mu$ l over $\sim 3 \mathrm{~min}$ ) $15 \mathrm{~min}$ before start of aIH. Nerve activity was monitored for $60 \mathrm{~min}$ after the last hypoxic episode while maintaining baseline levels of arterial blood gases. Blood samples $(0.1-0.2 \mathrm{ml}$ in a capillary tube) were drawn and analyzed before hypoxic challenge (baseline), during hypoxic challenge, and at 15, 30, and $60 \mathrm{~min}$ after hypoxia. At the conclusion of each experiment, rats were euthanized by urethane overdose administered via the femoral vein, followed by discontinuation of pump ventilation.

Quantification of circulating hormone levels. Although visualization of vaginal cell characteristics provide well established correlates to circulating sex hormones (in particular, estradiol), additional quantification of serum E2 and progesterone was performed using ELISAs (Zabka et al., 2005, 2006; Doperalski et al., 2008; Skucas et al., 2013; Czyzyk et al., 2014). Briefly, blood samples were collected before start of the aIH protocol and allowed to clot at room temperature for $15 \mathrm{~min}$. Samples were centrifuged at $3000 \mathrm{rpm} \times 10 \mathrm{~min}$ and serum was collected for storage at $-80^{\circ} \mathrm{C}$. Progesterone and estradiol concentrations were determined using ELISAs (Calbiotech) according to the manufacturer's instructions; all serum samples were run in triplicate. The absorbance was read at $450 \mathrm{~nm}$ and serum concentrations were interpolated from standard curves run in each assay.

Statistical analysis. For all neurophysiological recordings, peak amplitude and burst frequency of phrenic nerve activity were averaged in $1 \mathrm{~min}$ bins at each recorded data point (baseline, during hypoxic exposure, and 15,30 and $60 \mathrm{~min}$ after the final hypoxic episode). Baseline measures were taken just before the start of the first hypoxic challenge. Changes in nerve burst amplitudes were normalized as a percentage change above baseline values; baseline phrenic burst amplitudes were similar across experimental groups in all studies ( $p=0.698$ for the first group of studies, and $p=0.399$ for E2-BSA studies; one-way ANOVA). Burst frequency was analyzed and reported in bursts $\times \mathrm{min}^{-1}$. In the first group of studies, we compared phrenic nerve responses among all experimental groups, with the exception of the postpartum group (presented separately). Sham ovariectomy surgery had no discernable impact on phrenic nerve output compared with ovary-intact rats. Therefore, the estrus and proestrus groups each contain a combination of sham ovariectomy $(n=$ $4)$ and intact rats $(n=4)$. In addition, OVX rats receiving vehicle injections (intraperitoneal, oil) before phrenic nerve recordings $(n=3)$ were identical to OVX rats alone $(n=5)$. Thus, these groups were combined for analysis of phrenic nerve activity. Statistical comparisons in phrenic burst amplitude and frequency were made for time (baseline and 15, 30, and $60 \mathrm{~min}$ after hypoxia) and treatment effects using two-way repeatedmeasures ANOVA. Statistically significant interactions between time and treatment were observed ( $p \leq 0.003)$ and Tukey's post hoc tests were used to identify statistically significant individual comparisons. Since post hoc analyses of phrenic burst amplitude and frequency measures showed statistical significance only at $60 \mathrm{~min}$ after hypoxia, we limited our figures to this time point for ease of visual comparison. Physiological variables were compared across groups in the same manner, and data are presented for measurements taken at baseline, during hypoxic challenge, and $60 \mathrm{~min}$ after $\mathrm{aIH}(60 \mathrm{~min})$. Separate analyses of the phrenic nerve burst responses to hypoxia were made using a one-way ANOVA. Serum estradiol and progesterone levels were not normally distributed following ELISA, as anticipated. Therefore, statistical comparisons were made using logarithmically transformed datasets in a one-way ANOVA followed by Fisher's least significant difference post hoc tests. For all comparisons, differences were considered significant at $p<0.05$. All values are expressed as the mean \pm SEM.

\section{Results}

\section{pLTF expression varies by estrous cycle stage in young \\ female rats}

To determine whether the magnitude of aIH-induced respiratory motor plasticity differed depending on circulating estradiol levels, we measured pLTF in estrous cycle stages in which E2 levels were low (estrus) or at their peak (proestrus). Young proestrus female rats displayed a progressive and persistent increase in phrenic nerve burst amplitude over $60 \mathrm{~min}$ following aIH, indicative of pLTF (Mitchell and Johnson, 2003; Figure 1A). Consistent with prior reports (Zabka et al., 2001), young female rats in estrus failed to express pLTF (Fig. $1 B$ ); phrenic amplitudes were similar to baseline values $60 \mathrm{~min}$ following aIH $(10 \pm 5 \%$; $p=$ 0.263; Fig. $1 F)$ as well as to time-control rats $(p=0.945$; Fig. $1 F)$. Phrenic nerve amplitudes of proestrus females were significantly higher than those of baseline $(39 \pm 2 \%$; $p<0.001)$, estrus $(p<$ $0.001)$, and time-control $(p<0.001)$ females at $60 \mathrm{~min}($ Fig. $1 F)$. Thus, consistent with our hypothesis, the magnitude of aIHinduced pLTF in young female rats fluctuated with estrous cycle stage, in apparent relation to circulating E2 levels. Estrous cycle stage had no effect on the amplitude of the hypoxic response, as phrenic amplitudes increased to a similar extent in both proestrus rats $(79 \pm 9 \%)$ and estrus rats $(74 \pm 8 \%$; Fig. $1 G)$. Proestrus rats displayed a small, but statistically significant facilitation in phrenic burst frequency at $60 \mathrm{~min}$ after aIH $(4 \pm 1 \% ; p=0.013)$ compared with baseline; however, frequency in proestrus rats was not different from that of estrus rats $(p=0.786$; Fig. $1 H)$, and estrus rats exhibited no change in phrenic burst frequency 60 min following aIH relative to baseline $(p=0.408)$.

\section{Ovariectomy abolishes pLTF expression}

To determine whether ovarian-derived steroids were required for aIH-induced pLTF, we examined the expression of pLTF in OVX young female rats. As anticipated, ovariectomy eliminated the progressive increase in phrenic burst amplitude following aIH (Fig. 1C) that was observed in proestrus females (Fig. 1A). Indeed, at 60 min after aIH, phrenic burst amplitudes in OVX rats were not different from that of baseline $(7 \pm 5 \%$; $p=0.607)$, estrus $(p=0.99$; Fig. $1 F)$, or time-control rats $(p=0.945$; Fig. $1 F)$. Though the OVX group appeared to have a moderately blunted response to hypoxia $(60 \pm 7 \%)$, this was not statistically different from other experimental groups $(p=0.409$; Fig. $1 G)$. In addition, ovariectomy did not have a significant impact on phrenic burst frequency over time following aIH $(p=0.317)$, 


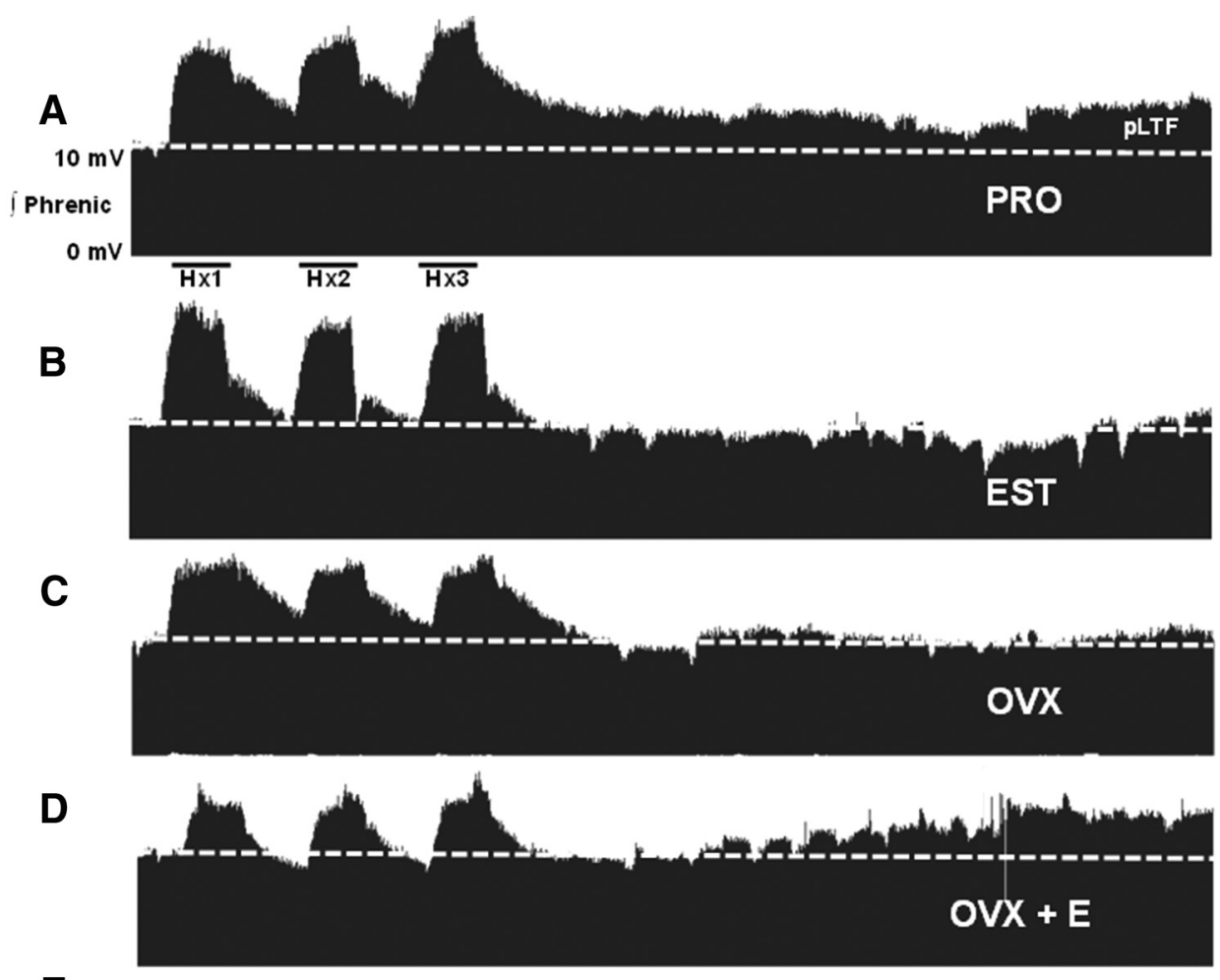

$\mathbf{E}$
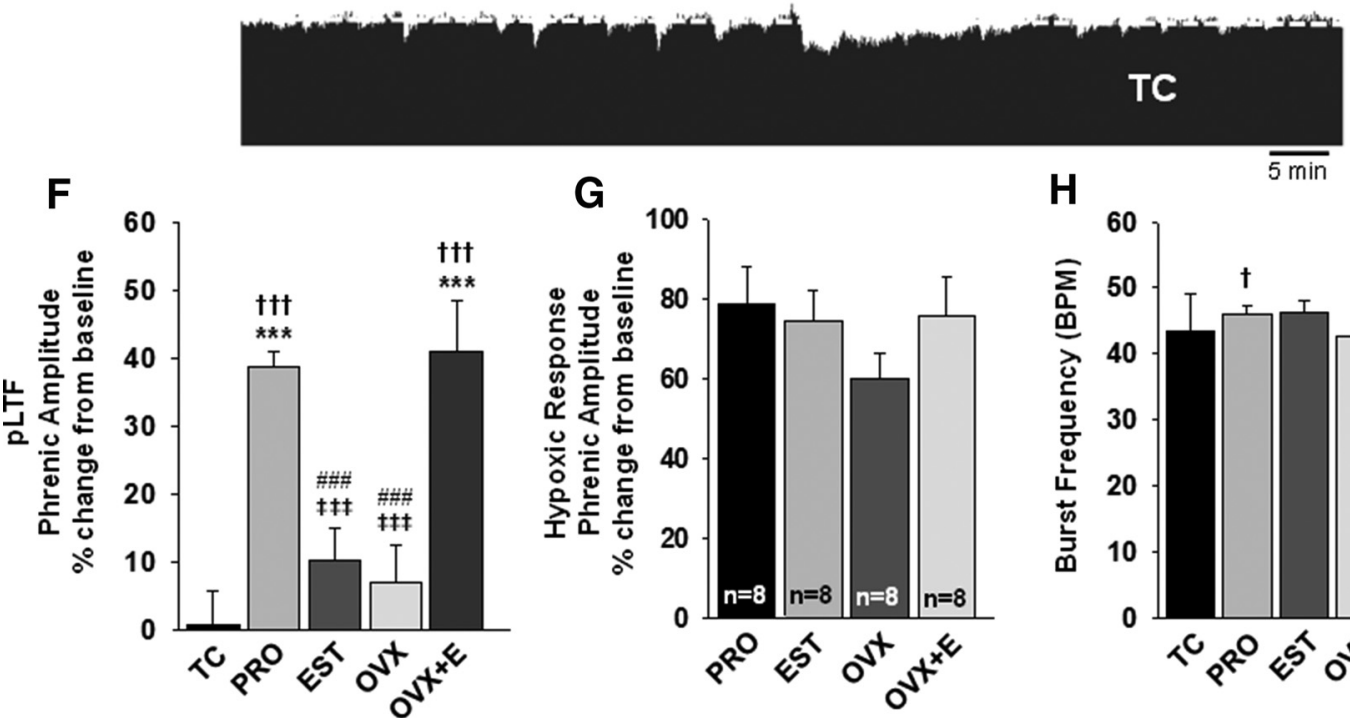

G

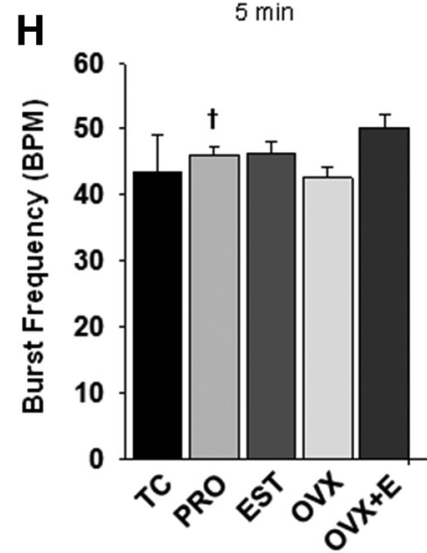

Figure 1. alH induces pLTF in young proestrus, but not estrus rats, and systemic E2 restores $\mathrm{pLTF}$ to $\mathrm{OVX}$ rats. Representative traces of integrated phrenic neurograms over $90 \mathrm{~min}$ during and following alH in young female rats. Baseline is indicated by the dashed line. All traces are identically scaled. $A$, Following exposure to alH, females in proestrus (PRO; $n=8)$ exhibit a progressive increase in phrenic nerve burst amplitude above baseline (dashed line). $\boldsymbol{B}$, Rats in estrus (EST; $n=8)$ do not express pLTF. $\boldsymbol{C}$, OVX rats $(n=8)$ failed to express pLTF. $\boldsymbol{D}$, E2 replacement (intraperitoneal) in OVX females (OVX $+\mathrm{E} ; n=8$ ) rescued pLTF. $E$, In the absence of alH, time-control (TC) rats $(n=5)$ displayed no time-dependent changes in phrenic nerve burst amplitudes over the same 90 min period. $\boldsymbol{F}$, Quantification of pLTF magnitude in all treatment groups at $60 \mathrm{~min}$ following alH, graphed as a percentage change from baseline. G, Phrenic nerve burst amplitudes in response to hypoxia, graphed as a percentage change from baseline. $\boldsymbol{H}$, Phrenic nerve burst frequency in bursts per minutes (BPM) 60 min after alH. ${ }^{\mathrm{tt \dagger}} p<0.001$, and ${ }^{\dagger} p<0.05$ versus baseline; ${ }^{* * *} p<0.001$ versus TC; ${ }^{* \neq \ddagger} p \leq 0.001$ versus $P R O ;{ }^{\# \# \#} p \leq 0.001$ versus $0 \mathrm{VX}+\mathrm{E}$.

and OVX rats had similar burst frequencies to estrus $(p=0.99$; Fig. $1 H)$ and proestrus rats $(p=0.847$; Fig. $1 H) 60$ min after aIH. Combined, these data support the hypothesis that ovarian steroids are necessary for pLTF expression in young female rats.

\section{Acute estradiol replacement in OVX rats restores pLTF}

Given the key role of estradiol in other forms of neuroplasticity, we hypothesized that estradiol would be sufficient to restore spi- nal pLTF in OVX females. To test this hypothesis, intraperitoneal EB was administered to OVX rats $3 \mathrm{~h}$ before assessment of pLTF. In preliminary experiments, EB administered $16-24 \mathrm{~h}$ before pLTF was insufficient to significantly restore pLTF (18 $\pm 10 \%$; $n=5)$. OVX rats pretreated with $\mathrm{EB}(\mathrm{OVX}+\mathrm{E})$ for $3 \mathrm{~h}$ before pLTF, however, displayed a progressive and persistent increase in phrenic burst amplitude in response to aIH (Fig. 1D). Indeed, 60 min following aIH, phrenic burst amplitudes in the 
$\mathrm{OVX}+\mathrm{E}$ rats were significantly higher than those of baseline $(41 \pm 7 \% ; p<0.001)$, estrus $(p<0.001)$, OVX $(p<0.001)$, and time-control rats $(p<0.001$; Fig. $1 F)$. Hypoxic responses were similar to all other treatment groups (Fig. $1 G$ ). Rats treated with EB showed a modest increase in phrenic burst frequency over time following aIH relative to baseline ( $4 \pm$ $2 \%$; $p=0.052$; Fig. $1 H$ ), but at 60 min after aIH, phrenic burst frequency in the OVX + E group was statistically similar to that of all other treatment groups (Fig. $1 H$ ).

\section{Serum estradiol levels positively correlate with pLTF expression}

Estrous cycle stage and the efficacy of E2 replacement was confirmed by measuring serum E2 and progesterone levels with an ELISA. Serum E2 levels in proestrus rats $(33 \pm 4 \mathrm{pg} / \mathrm{ml})$ were significantly higher than in estrus $(7 \pm 2 \mathrm{pg} / \mathrm{ml})$ and OVX rats ( $3 \pm 0.5 \mathrm{pg} / \mathrm{ml} ; p<0.001$ for both comparisons; Fig. $2 A$ ). Average serum E2 levels in the OVX $+\mathrm{E}$ group $(82 \pm 23 \mathrm{pg} / \mathrm{ml})$ were not statistically different from E2 levels in proestrus rats $(p=$ 0.21 ; Fig. $2 A)$, but were significantly higher than in estrus and OVX rats ( $p<0.001$ for both comparisons; Fig. $2 A$ ). There was a significant positive correlation between serum E2 levels and the magnitude of pLTF $(r=0.475 ; p=0.007$; Fig. $2 B)$. Serum progesterone levels were similar between females in proestrus $(24 \pm$ $3 \mathrm{ng} / \mathrm{ml})$ and estrus $(27 \pm 4 \mathrm{ng} / \mathrm{ml} ; p=0.83$; Fig. $2 C)$. Progesterone levels dropped following ovariectomy $(17 \pm 2 \mathrm{ng} / \mathrm{ml})$ and were not affected by E2 replacement $(15 \pm 2 \mathrm{ng} / \mathrm{ml}, p=0.46$; Fig. $2 C)$. However, while progesterone levels in the OVX $+\mathrm{E}$ group were significantly reduced compared with those in proestrus and estrus rats ( $p=0.03$ and $p=0.02$, respectively for each; Fig. $2 C$ ), progesterone levels in the proestrus and estrus groups were not different from those in rats with ovariectomy alone ( $p=0.12$ vs proestrus; $p=0.08$ to estrus). This unexpected result was likely influenced by a single rat in the estrus group with extremely low circulating progesterone; when this rat was removed from the analysis, progesterone levels in the OVX group were significantly lower than those of estrus rats $(p=0.004)$, and showed a reduction in serum progesterone levels compared with levels in the proestrus group $(p=0.06)$. Nevertheless, we retained this rat in the overall analysis as an example of normal biological variability among subjects (Lee et al., 2011), and to show the significant fluctuations in circulating ovarian hormones that occur over very short time domains of the normal rat estrous cycle. Unlike serum E2 levels, there was no apparent linear relationship between serum progesterone and pLTF expression, as evidenced by a flattened, negative regression ( $r=-0.047, p=0.802$; Fig. $2 D)$.

Since previous studies indicated a correlation between serum progesterone/estradiol $(\mathrm{P} / \mathrm{E})$ ratios and respiratory motor plasticity (Zabka et al., 2003), we calculated the P/E ratios in our study, and performed regression analyses across treatment groups. Due to elevated estradiol levels in proestrus and $\mathrm{OVX}+\mathrm{E}$ rats, there was a statistically significant reduction in the $\mathrm{P} / \mathrm{E}$ ratio in proestrus and OVX + E groups compared with estrus and OVX groups $(p<0.001$ for each; Fig. $2 E)$; OVX $+E$ rats had a lower $\mathrm{P} / \mathrm{E}$ ratio compared with proestrus rats $(p=0.04 ;$ Fig. $2 E)$. Accordingly, we observed a significant negative correlation between the P/E ratio and pLTF $(r=$ $-0.404 ; p=0.024$; Fig. $2 F)$.

\section{pLTF is not expressed in postpartum, lactating female rats}

To further investigate the relationship between the $\mathrm{P} / \mathrm{E}$ ratio and the magnitude of pLTF expression, we tested the hypothesis that pLTF would be absent during periods in which normal levels of circulating progesterone, but not estrogen, are elevated. To this end, we studied a separate cohort of ovary-intact, postpartum, lactating female rats within the first $10 \mathrm{~d}$ postpartum. We found that postpartum rats lacked the progressive increase in phrenic nerve burst amplitude following aIH (Fig. $3 A$ ); compared with baseline, postpartum phrenic burst amplitudes were similar 60 min following aIH ( $-4 \pm 11 \%$; Fig. $3 B$ ). Notably, however, postpartum rats exhibited robust hypoxic responses (227 $\pm 87 \%$; Fig. $3 C$ ) followed by periods of apnea in phrenic nerve activity (Fig. $3 A$ ); this was not observed in any other treatment group investigated. No appreciable effects on phrenic nerve burst frequency were observed over time following aIH (data not shown). Serum estradiol levels were predictably low ( $5 \pm 0.8 \mathrm{pg} / \mathrm{ml}$; Fig. $3 D)$ and serum progesterone levels were elevated ( $32 \pm 4 \mathrm{ng} / \mathrm{ml}$; Fig. $3 E$ ). Progesterone levels were comparable to those in proestrus and estrus rats.

\section{Estradiol-induced restoration of pLTF in OVX females involves nongenomic, spinal mechanisms}

The relatively short time frame during which intraperitoneal E2 restored pLTF expression in OVX rats $(3 \mathrm{~h})$, and the observation that PLTF was not restored in OVX rats with longer times of E2 treatment (i.e., 16-24 h) led us to consider the possibility that E2 may be acting via rapid, nongenomic cellular mechanisms directly at the level of the spinal cord to restore pLTF as occurs in other areas of the CNS (McEwen and Alves, 1999; Balthazart and Ball, 2006; Srivastava et al., 2011; Bean et al., 2014; Frick, 2015). To test this, a membrane-impermeable E2-BSA (Wu et al., 2011) was delivered intrathecally over the region of the phrenic motor nucleus in OVX rats 15 min before aIH. E2-BSA activates membrane $\mathrm{E} 2$ receptors that induce rapid effects on multiple cellular signaling pathways that can affect protein translation (Pietras and Szego, 1977; Pappas et al., 1995; Milner et al., 2001, 2005). This contrasts with the slower-developing effects on gene transcription that result from nuclear E2 receptor activation (McEwen and Alves, 1999; Balthazart and Ball, 2006; Srivastava et al., 2011; Bean et al., 2014; Frick, 2015). aIH induced a robust increase in phrenic nerve amplitude in the spinal E2-BSA-treated OVX rats relative to baseline $(54 \pm 10 \%$; $p<0.001)$, BSA-treated control rats $(\mathrm{BSA} ; p=0.012)$, and time-control rats $(p=0.001 ;$ Fig. $4 A)$. Modest increases in phrenic burst amplitude were observed in both BSA control rats $(18 \pm 3 \% ; p=0.053)$ and time-control rats $(10 \pm 2 \% ; p=0.607)$ over the $60 \mathrm{~min}$ after aIH interval relative to baseline. However, these groups remained statistically similar to each other 60 min after aIH ( $p=0.744$; Fig. $4 A$ ). E2-BSA also had a significant impact on phrenic burst amplitude during hypoxic challenge. Rats treated with E2-BSA showed a robust increase in phrenic nerve burst amplitude $(173 \pm 18 \%)$ relative to baseline; nearly double that observed in BSA-treated control rats $(86 \pm$ $25 \%$; $p=0.022$; Fig. $4 B$ ). Neither E2-BSA nor BSA alone had a significant impact on phrenic nerve burst frequency (Fig. 4C).

\section{Physiological variables}

Physiological variables quantified during neurophysiological experiments are shown in Table 1. The following blood-gas criteria were maintained in all rats during pLTF experiments: (1) body temperature of $38^{\circ} \mathrm{C} \pm 1^{\circ} \mathrm{C}$; (2) $\mathrm{PaCO}_{2}$ within $1.5 \mathrm{mmHg}$ of baseline during hypoxic challenge and throughout the post-aIH recovery period; (3) $\mathrm{PaO}_{2}$ during the hyperoxic baseline and recovery periods $>250 \mathrm{mmHg}$ and $\mathrm{PaO}_{2}$ between 35 and $45 \mathrm{mmHg}$ during hypoxic episodes (Dale-Nagle et al., 2010; Devinney et al., 2013; Dougherty et al., 2015); and (4) SBE $\pm 3.0 \mathrm{mEq} / \mathrm{L}$, ensuring appropriate acid-base regulation. 
A

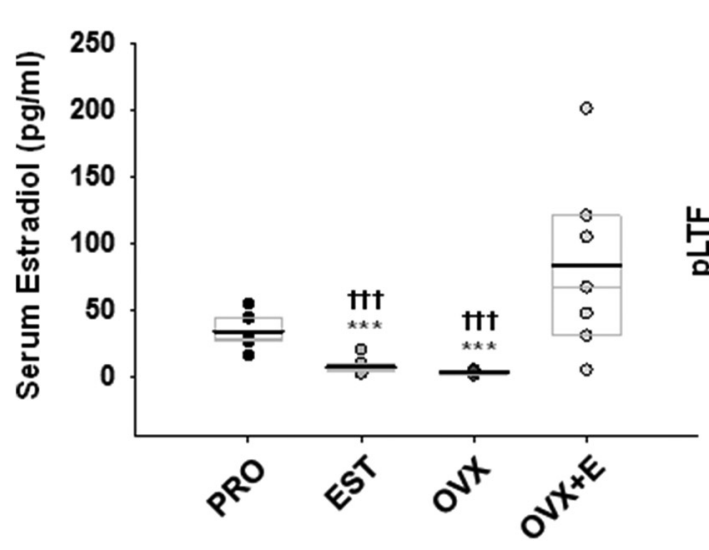

C

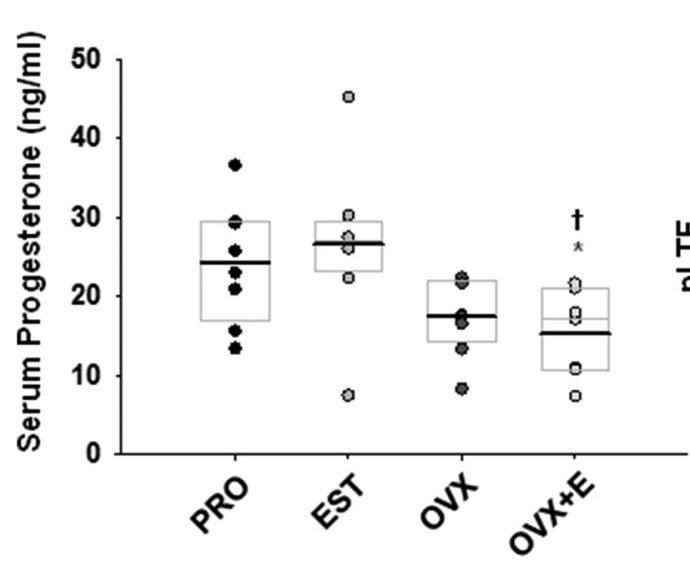

$\mathbf{E}$

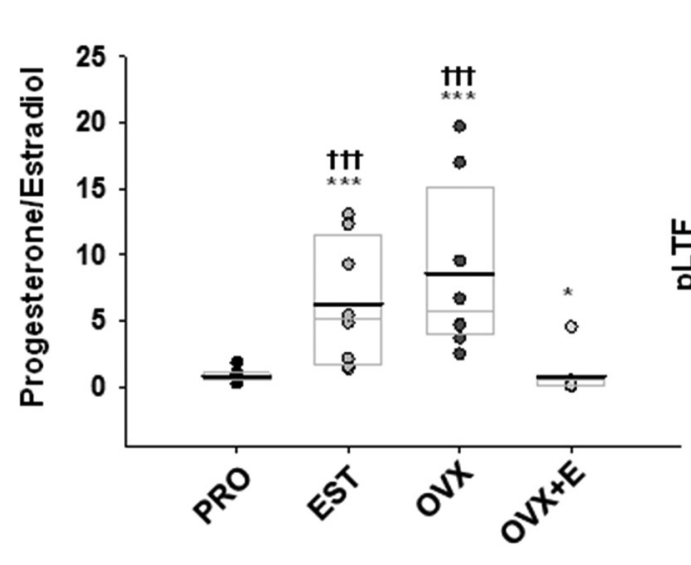

B

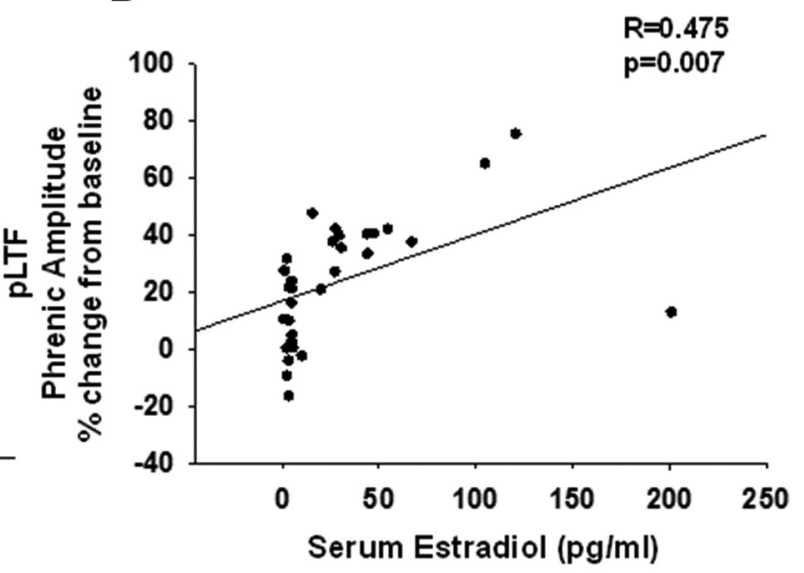

D

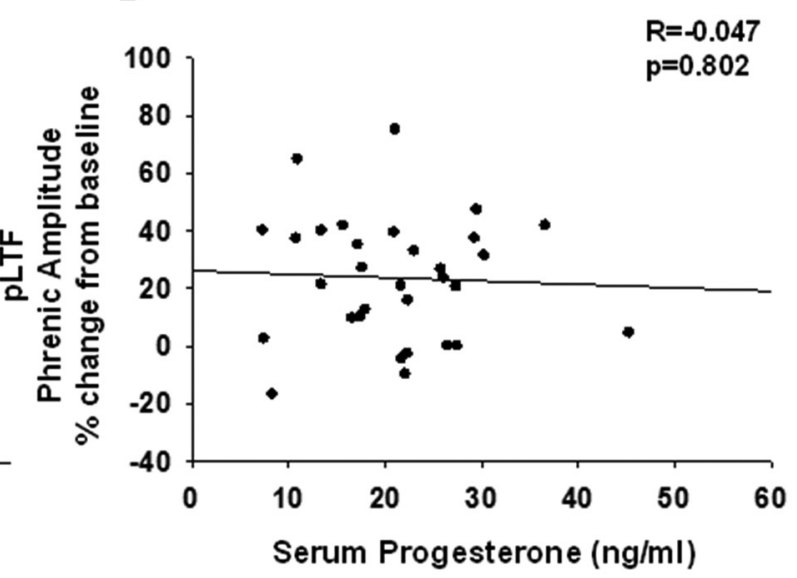

$\mathbf{F}$

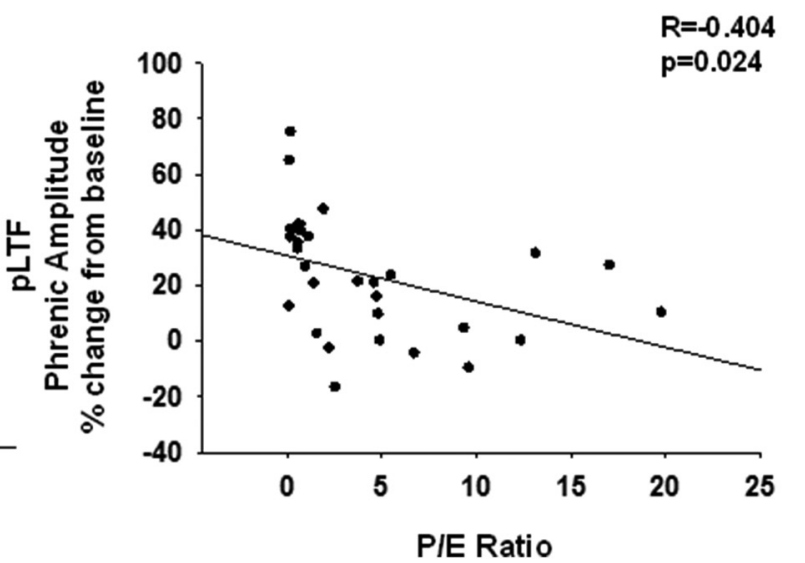

Figure 2. pLTF positively correlates with serum E2 levels, and inversely correlates with the P/E ratio. A, Serum E2 levels were significantly elevated in proestrus (PRO) and OVX $+E$ rats relative to estrus (EST) and OVX rats. $\boldsymbol{B}$, Regression analyses of serum E2 levels, which positively correlated with the magnitude of pLTF 60 min after alH. C, Serum progesterone levels were reduced in $0 V X$ and OVX +E rats. D, Serum progesterone levels did not correlate with pLTF. $E$, The P/E ratios in the PRO and OVX+E groups were significantly lower than P/E ratios in the EST and OVX groups. $F$, The P/E ratio negatively correlated with $\mathrm{pLTF} .{ }^{* * *} p<0.001$ and ${ }^{*} p<0.05$ versus $\mathrm{PRO} ;{ }^{\mathrm{tt}} p \leq 0.001$ versus $\mathrm{OVX}+\mathrm{E} ;{ }^{\ddagger} p<0.05$ versus EST. Overlaid box plots indicate the 25 th and 75 th percentile, and the median of each dataset; group means are denoted by bold lines.

In the first set of phrenic recording experiments, body temperatures in OVX rats were higher than those of proestrus $(p=$ $0.010)$ and estrus $(p=0.008)$ rats during hypoxic challenge, and $\mathrm{OVX}+\mathrm{E}$ rats had higher temperatures at 60 min compared with hypoxia $(p=0.011)$. However, temperatures remained within our set criteria throughout, and average temperatures differed by $<1^{\circ} \mathrm{C}$. Blood $\mathrm{pH}$ was unchanged across all treatment groups in all conditions. $\mathrm{PaCO}_{2}$ was regulated within $1.5 \mathrm{mmHg}$ of baseline measurements in all groups and all conditions as per standard criteria; however, there was a statistically significant reduction in $\mathrm{PaCO}_{2}$ in time-control rats over time $(p=0.009)$. As anticipated, all experimental groups showed a significant decrease in $\mathrm{PaO}_{2}$ 


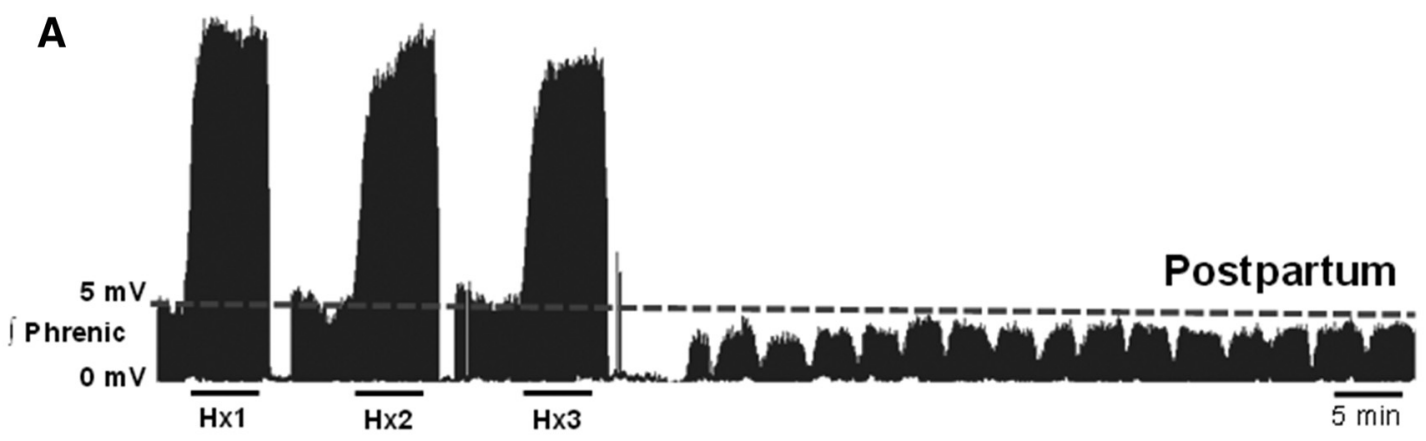

B

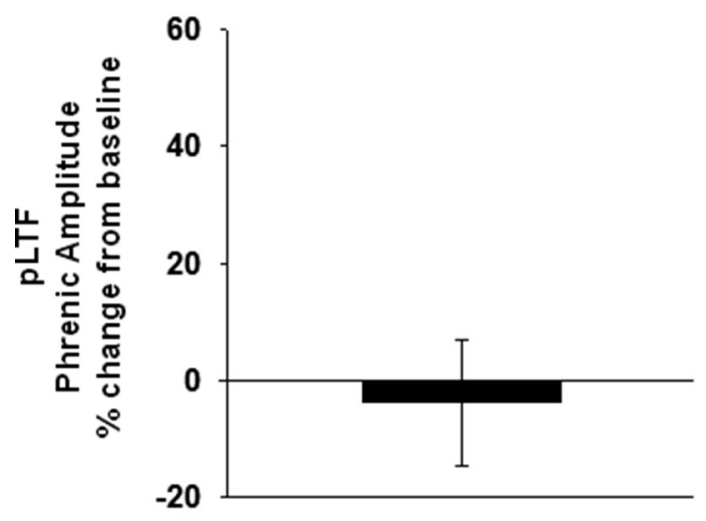

D

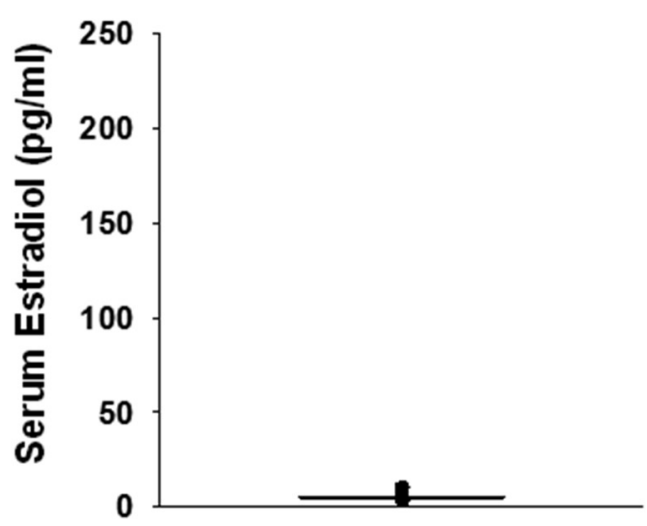

C

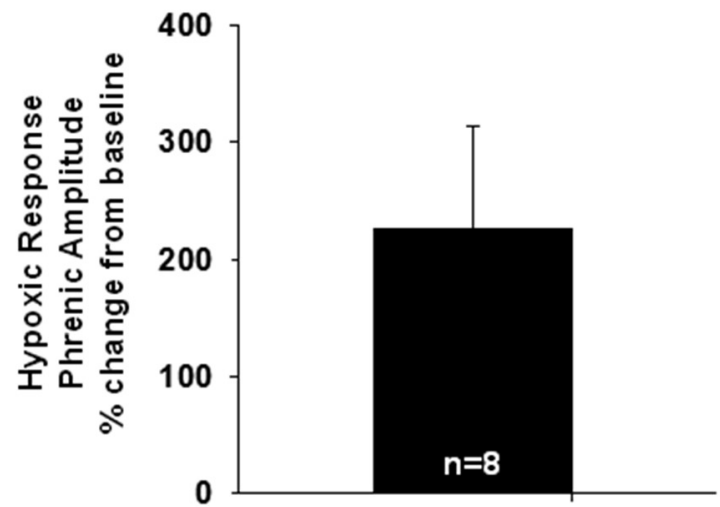

E

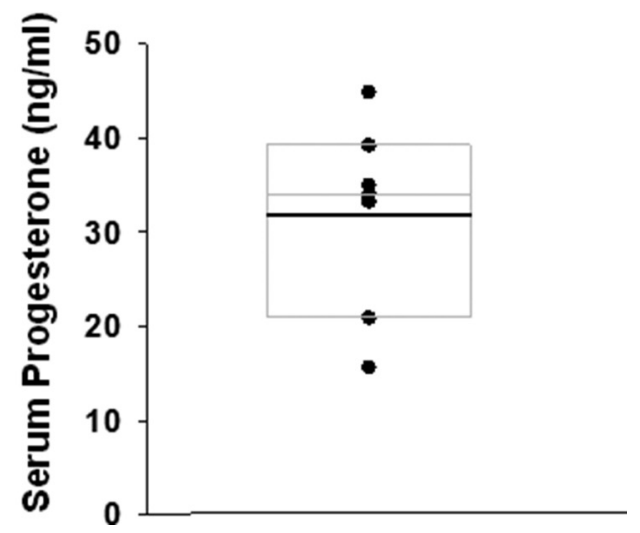

Figure 3. pLTF is absent in postpartum, lactating female rats despite elevated progesterone levels. $A$, Representative trace of an integrated phrenic neurogram over 90 min during and following alH in postpartum, lactating rats. Baseline is indicated by the dashed line. $B$, Quantification of phrenic nerve burst amplitudes $60 \mathrm{~min}$ after alH, graphed as percentage change from baseline; $\mathrm{pLTF}$ was not observed $(n=8)$. C, Phrenic nerve burst amplitudes in response to hypoxia, graphed as a percentage change from baseline, showed a robust response to hypoxia. $\boldsymbol{D}, \boldsymbol{E}$, Serum E2 levels were low $(\boldsymbol{D})$ and serum progesterone levels approximated those in proestrus and estrus rats $(\boldsymbol{E})$. Overlaid box plots indicate the 25 th and 75 th percentiles, and the median of each dataset; group means are denoted by bold lines.

during hypoxia $(p<0.001)$ that recovered by $60 \mathrm{~min}$ after aIH. $\mathrm{PaO}_{2}$ was similar between groups during baseline and at $60 \mathrm{~min}$ after aIH. Also, despite a reduction in $\mathrm{PaO}_{2}$ over time in proestrus rats relative to baseline ( $p=0.002), \mathrm{PaO}_{2}$ levels remained well within established ranges $(>250 \mathrm{mmHg})$. SBE remained well within set criteria $(-3.0$ to $+3.0 \mathrm{mEq} / \mathrm{L})$ in all groups, across all conditions, and likely had little impact on pLTF expression despite fluctuating in time-control groups $(p=0.009)$.

As expected, hypoxic challenge resulted in a significant reduction in mean arterial pressure (MAP) in all experimental groups compared with baseline; $\mathrm{OVX}+\mathrm{E}$ rats displayed the greatest decline. In addition, a persistent reduction in MAP relative to baseline values was observed in most experimental groups at the 60 min time point after aIH, consistent with previous pLTF studies. In prior studies, rats were eliminated from statistical analyses if the reduction in MAP at $60 \mathrm{~min}$ after aIH was $>30$ $\mathrm{mmHg}$ from baseline (Dougherty et al., 2015); in this study, reductions of this magnitude were not observed in any group at $60 \mathrm{~min}$ after aIH. Further, all groups had similar MAP at the 60 min time point. 

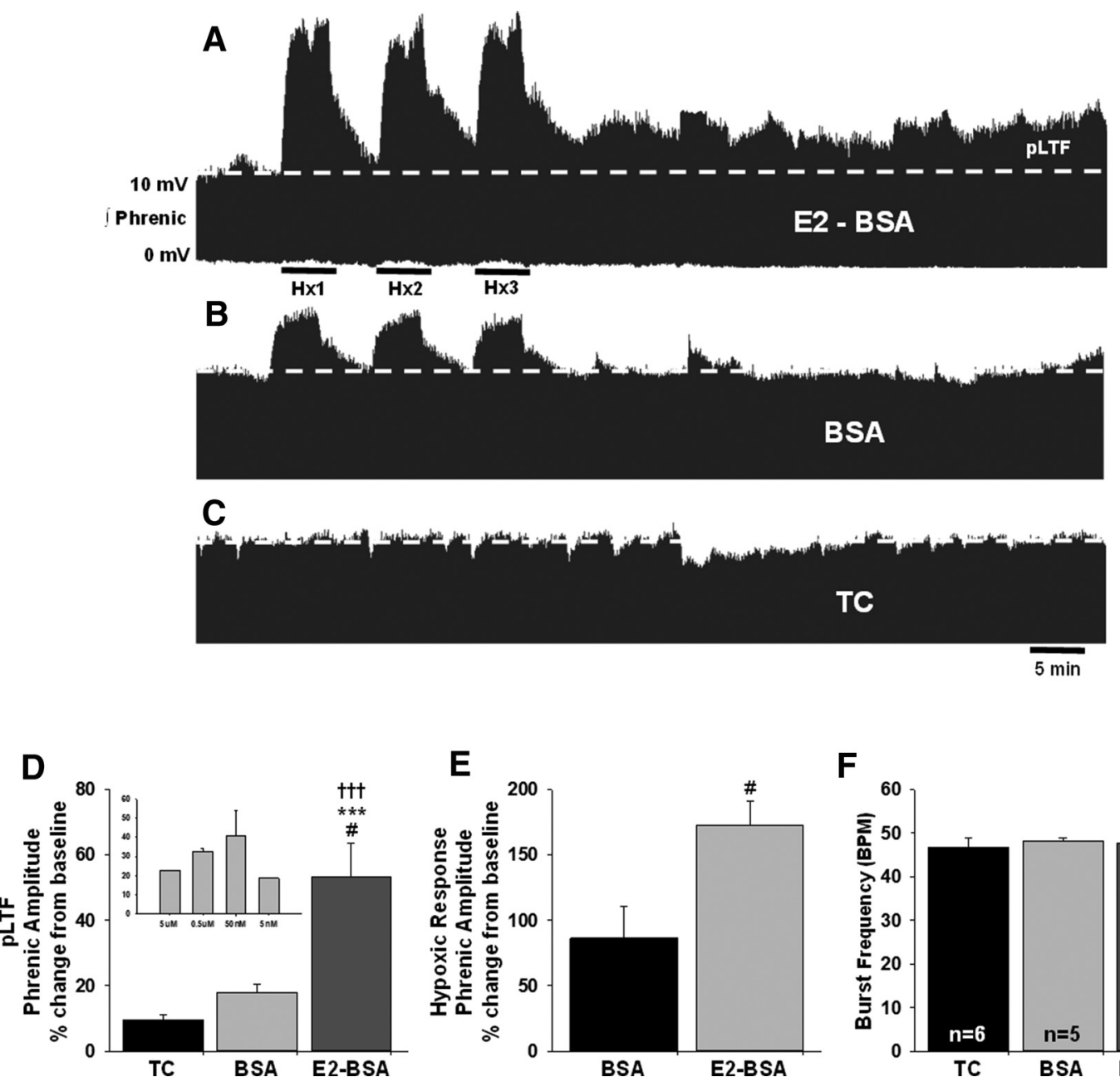

E

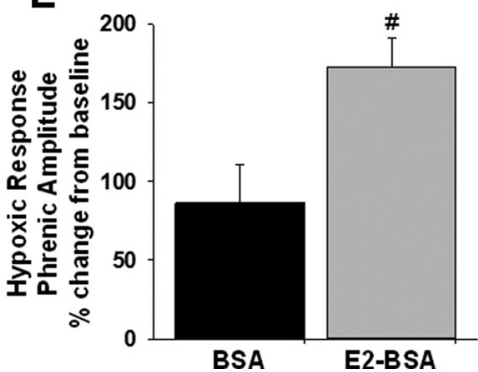

$\mathbf{F}$

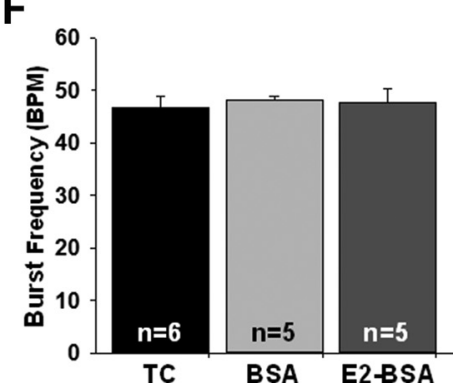

Figure 4. Activation of spinal membrane ERs with intrathecal E2-BSA restores pLTF in OVX rats. $A, B$, Representative traces of integrated phrenic neurograms over 90 min during and following alH in OVX female rats receiving intrathecal $(\boldsymbol{A}) \mathrm{E2}-\mathrm{BSA}(n=5)$ to activate membrane E2 receptors or $(\boldsymbol{B})$ control BSA alone $(n=5)$. Baseline is indicated by the dashed line. E2-BSA given 15 min before alH resulted in a progressive increase in phrenic nerve burst amplitude above baseline (dashed line). Rats receiving BSA alone did not express pLTF. C, In the absence of alH, time-control (TC) rats $(n=6)$ receiving intrathecal injections displayed no time-dependent changes in phrenic nerve burst amplitudes over the same 90 min period. $D$, Quantification of pLTF magnitude following pretreatment with intrathecal E2-BSA or BSA alone reflect an E2-BSA-induced enhancement of phrenic burst amplitude $60 \mathrm{~min}$ following alH relative to baseline, BSA-treated control rats, and time controls. The $50 \mathrm{~nm}$ E2-BSA dose was derived from dose-response studies (inset). $\boldsymbol{E}, \boldsymbol{F}$, Intrathecal E2-BSA led to enhanced phrenic amplitude in response to hypoxia $(\boldsymbol{E})$, but had minimal impact on phrenic burst frequency $(\boldsymbol{F})$.

During intrathecal experiments, modest but statistically significant reductions in body temperature were observed for both experimental groups during hypoxic challenge. However, as with the first set of studies, temperatures remained within our established criteria and did not vary by $>1^{\circ} \mathrm{C} . \mathrm{PaCO}_{2}$ and $\mathrm{pH}$ were similar across all groups in all conditions. In experimental groups, hypoxic challenge caused a significant reduction in $\mathrm{PaO}_{2}$ $(p<0.001)$, which returned to normal by $60 \mathrm{~min}$. Experimental groups received similar levels of hypoxia that fell within targeted ranges (i.e., $35-45 \mathrm{mmHg}$ ). SBE also remained steady across all groups in all conditions. Consistent with our first set of neurophysiological recordings, MAP was significantly reduced during hypoxic challenge in both experimental groups $(p<0.001)$ but returned to baseline levels by $60 \mathrm{~min}$ after aIH. It is notable that MAP in these studies was generally lower in all conditions than in studies without intrathecal injections, but these reductions were consistently observed across all groups.

\section{Discussion}

These original data suggest that ovarian hormones (and E2 specifically) are necessary for normal pLTF expression in young fe- male rats. Importantly, E2 can restore pLTF to OVX rats, within $15 \mathrm{~min}$, through mechanisms involving activation of spinal membrane ERs. This is the first report to directly test the role of ER signaling in respiratory neuroplasticity in either sex, and to demonstrate a role for rapid, membrane effects of E2 in restoring this form of spinal neuroplasticity. Few respiratory plasticity studies have been conducted in females and fewer still, in young, cycling females (Zabka et al., 2001; Behan et al., 2003). Thus, most of what is known about this form of respiratory plasticity is based on studies performed in males. Although testosterone conversion to estradiol is necessary for pLTF in castrated males (Zabka et al., 2006), ovarian function or the effects of estrogen administration on pLTF in either sex have not been explored.

Here, we studied young females during the proestrus and estrus phases of the estrous cycle, when estradiol levels are high and low, respectively (Smith et al., 1975; Woolley, 2007). pLTF was only present in proestrus, not estrus, suggesting that high estrogen levels may be necessary for pLTF. To further test this idea, we ovariectomized rats and replaced them with estrogen $3 \mathrm{~h}$ before $\mathrm{aIH}$ exposure. We found that while ovariectomy eliminated 
Table 1. Physiological variables during phrenic nerve recordings

\begin{tabular}{|c|c|c|c|c|c|c|c|}
\hline Condition & Treatment & Body temperature $\left({ }^{\circ} \mathrm{C}\right)$ & $\mathrm{pH}$ & $\mathrm{PaCO}_{2}(\mathrm{mmHg})$ & $\mathrm{PaO}_{2}(\mathrm{mmHg})$ & $\operatorname{SBE}\left(\mathrm{mEq}^{*} \mathrm{~L}^{-1}\right)$ & $\operatorname{MAP}(\mathrm{mmHg})$ \\
\hline \multicolumn{8}{|c|}{ Physiological variables for cycling and OVX females } \\
\hline \multirow[t]{5}{*}{ Baseline } & Time control & $37.8 \pm 0.1$ & $7.350 \pm 0.012$ & $49 \pm 1$ & $320 \pm 7$ & $1.06 \pm 0.87$ & $108 \pm 7$ \\
\hline & Proestrus & $37.3 \pm 0.1$ & $7.341 \pm 0.015$ & $47 \pm 2$ & $335 \pm 6$ & $-0.55 \pm 0.52$ & $125 \pm 3$ \\
\hline & Estrus & $37.2 \pm 0.1$ & $7.309 \pm 0.008$ & $51 \pm 1$ & $339 \pm 8$ & $-0.60 \pm 0.34$ & $117 \pm 7$ \\
\hline & ovx & $38.0 \pm 0.3$ & $7.338 \pm 0.010$ & $49 \pm 2$ & $319 \pm 2$ & $0.11 \pm 0.63$ & $118 \pm 4$ \\
\hline & $\mathrm{OVX}+\mathrm{E}$ & $37.9 \pm 0.1$ & $7.353 \pm 0.008$ & $49 \pm 1$ & $316 \pm 10$ & $1.46 \pm 0.45$ & $115 \pm 5$ \\
\hline \multirow[t]{5}{*}{ Hypoxia } & Time control (no hypoxia) & $37.8 \pm 0.1$ & $7.346 \pm 0.014$ & $49 \pm 1$ & $322 \pm 6^{*}$ & $1.16 \pm 0.92$ & $109 \pm 8$ \\
\hline & Proestrus & $37.2 \pm 0.1^{f}$ & $7.329 \pm 0.015$ & $47 \pm 2$ & $41 \pm 2^{\#}$ & $-1.36 \pm 0.48$ & $91 \pm 10^{c}$ \\
\hline & Estrus & $37.2 \pm 0.1^{f}$ & $7.304 \pm 0.011$ & $51 \pm 2$ & $39 \pm 1^{\#}$ & $-1.00 \pm 0.38$ & $95 \pm 6^{b}$ \\
\hline & ovx & $38.2 \pm 0.4$ & $6.825 \pm 0.494$ & $50 \pm 2$ & $40 \pm 1^{\#}$ & $-0.33 \pm 0.38$ & $85 \pm 9^{\#}$ \\
\hline & $\mathrm{OVX}+\mathrm{E}$ & $37.8 \pm 0.1$ & $7.343 \pm 0.011$ & $49 \pm 2$ & $42 \pm 1^{\#}$ & $0.66 \pm 0.56$ & $64 \pm 9^{\#}$ \\
\hline \multirow[t]{5}{*}{$60 \mathrm{~min}$} & Time control & $37.8 \pm 0.3$ & $7.347 \pm 0.011$ & $48 \pm 1^{e}$ & $320 \pm 5$ & $0.36 \pm 0.92^{e}$ & $107 \pm 5$ \\
\hline & Proestrus & $37.5 \pm 0.2$ & $7.333 \pm 0.010$ & $47 \pm 2$ & $308 \pm 11^{b}$ & $-1.13 \pm 0.35$ & $105 \pm 7^{a}$ \\
\hline & Estrus & $37.3 \pm 0.1$ & $7.318 \pm 0.008$ & $51 \pm 2$ & $325 \pm 6$ & $0.03 \pm 0.30$ & $111 \pm 5^{d}$ \\
\hline & ovX & $37.9 \pm 0.3$ & $7.353 \pm 0.013$ & $49 \pm 2$ & $320 \pm 6$ & $1.19 \pm 0.54$ & $103 \pm 5^{a}$ \\
\hline & $\mathrm{OVX}+\mathrm{E}$ & $38.1 \pm 0.2^{d}$ & $7.344 \pm 0.009$ & $49 \pm 1$ & $320 \pm 9$ & $0.66 \pm 0.24$ & $96 \pm 5^{c}$ \\
\hline \multicolumn{8}{|c|}{ Physiological variables for OVX and E2-BSA females } \\
\hline \multirow[t]{3}{*}{ Baseline } & Time control & $37.6 \pm 0.1$ & $7.332 \pm 0.016$ & $48 \pm 1$ & $306 \pm 4$ & $-0.57 \pm 1.03$ & $73 \pm 4$ \\
\hline & BSA & $37.6 \pm 0.2$ & $7.327 \pm 0.007$ & $50 \pm 2$ & $287 \pm 19$ & $-0.08 \pm 0.94$ & $68 \pm 4$ \\
\hline & E2-BSA & $37.8 \pm 0.1$ & $7.341 \pm 0.010$ & $49 \pm 2$ & $290 \pm 10$ & $0.78 \pm 0.83$ & $76 \pm 6$ \\
\hline \multirow[t]{3}{*}{ Hypoxia } & Time control (no hypoxia) & $37.5 \pm 0.1$ & $7.334 \pm 0.016$ & $47 \pm 1$ & $312 \pm 4^{*}$ & $-0.57 \pm 0.90$ & $74 \pm 3^{*}$ \\
\hline & BSA & $37.4 \pm 0.2^{a}$ & $7.313 \pm 0.011$ & $51 \pm 2$ & $42 \pm 1^{\#}$ & $-0.44 \pm 0.56$ & $21 \pm 8^{\#}$ \\
\hline & E2-BSA & $37.4 \pm 0.1^{\#}$ & $7.325 \pm 0.015$ & $50 \pm 2$ & $41 \pm 1^{\#}$ & $-0.20 \pm 0.66$ & $23 \pm 2^{\#}$ \\
\hline \multirow[t]{3}{*}{$60 \mathrm{~min}$} & Time control & $37.5 \pm 0.1$ & $7.335 \pm 0.017$ & $49 \pm 2$ & $315 \pm 10$ & $-0.03 \pm 0.95$ & $73 \pm 5$ \\
\hline & BSA & $37.5 \pm 0.2$ & $7.318 \pm 0.015$ & $49 \pm 3$ & $307 \pm 10$ & $-0.86 \pm 0.66$ & $61 \pm 4$ \\
\hline & E2-BSA & $37.9 \pm 0.1$ & $7.332 \pm 0.012$ & $50 \pm 2$ & $294 \pm 8$ & $0.24 \pm 0.88$ & $66 \pm 6$ \\
\hline
\end{tabular}

Values are means $\pm \mathrm{SEM}$ for body temperature, $\mathrm{pH}, \mathrm{PaCO}, \mathrm{PaO}_{2}, \mathrm{SBE}$, and MAP for each group during baseline, hypoxia, and 60 min post-alH conditions. All variables remained within standard de novo criteria within each treatment group and across each condition.

${ }^{a} p<0.05 ;{ }^{b} p<0.01 ; p<0.001$ versus same treatment in baseline; ${ }^{d} p<0.05 ;{ }^{e} p<0.01$ versus same treatment in hypoxia condition; ${ }^{f} p<0.01$ versus 0 VX in same condition; ${ }^{*} p<0.001$ versus other treatments in hypoxia condition; $\# p<0.001$ versus same treatment in both baseline and $60 \mathrm{~min}$ conditions.

pLTF, E2 could reinstate this form of neuroplasticity, suggesting that estrogen may be the primary ovarian hormone required for pLTF. The idea that ovarian estrogen may be important for spinal respiratory neuroplasticity is consistent with the significant literature implicating a critical role for ovarian-derived E2 in the expression of other forms of CNS plasticity (McEwen et al., 1991; Romeo et al., 2004; Cooke and Woolley, 2005; Frick, 2015), including hippocampal LTP (Córdoba Montoya and Carrer, 1997; Foy et al., 1999; Smith and McMahon, 2005, 2006; Spencer et al., 2008; Smith et al., 2009; Fester and Rune, 2015).

The P/E ratio had been previously suggested to inversely correlate with pLTF in young estrus and diestrus females (Zabka et al., 2003). Thus, another goal of this study was to capitalize on the unique period of high $\mathrm{P} / \mathrm{E}$ ratio in young, early postpartum, ovary-intact rats. We found that lactating, postpartum rats did not exhibit pLTF in response to aIH, suggesting that progesterone at physiologic postpartum levels are insufficient to restore pLTF in the context of low estradiol. To our knowledge, this is the first study of respiratory motor plasticity in lactating, postpartum female rats. At the onset of parturition, rats experience a complex and profound change in endocrine function that may alter their capacity for neuroplasticity (Lévy et al., 2011; Galea et al., 2014). For example, the progressive increase in progesterone during early pregnancy, which peaks around gestational day 16 (Morishige et al., 1973), is followed by a precipitous drop at parturition to nearly undetectable plasma levels (Pepe and Rothchild, 1974; Rosenblatt et al., 1988). However, within hours postpartum, serum progesterone levels robustly increase again (coinciding with initiation of lactation), and they remain elevated until at least the eighth postpartum day (Grota and Eik-Nes, 1967). Also of im- portance, while progesterone levels are high during the early postpartum period, serum E2 levels are reduced within the first $14 \mathrm{~d}$ (Darnaudéry et al., 2007), resulting in an increased P/E ratio (Knobil and Neill, 1994). However, progesterone and estrogen are not the only hormones that are altered postpartum. Fluctuations in other circulating hormones, such as oxytocin, prolactin, and glucocorticoids, are known to affect hippocampal plasticity (Galea et al., 2014), and may also affect respiratory plasticity, although this has yet to be tested in detail. In addition, other physiologic variables in this postpartum experimental group may affect respiratory function and pLTF expression, including parity, litter size, physical changes in the abdominal area, and behavioral changes associated with lactation (e.g., suckling, cleaning behaviors). These variables notwithstanding, postpartum rats produced phrenic responses to hypoxia that were more robust relative to other treatment groups, and they displayed periods of prolonged apnea following each hypoxic challenge. An elevated $\mathrm{P} / \mathrm{E}$ ratio may be sufficient to explain the exaggerated response to respiratory challenge as progesterone is a potent respiratory stimulant (Dempsey et al., 1986; Tatsumi et al., 1997) that has been used in clinical settings to treat respiratory insufficiency (Dempsey et al., 1986; Kimura et al., 1986, 1988; Tatsumi et al., 1997). However, sufficient circulating E2 may be needed for the respiratory stimulating effects of progesterone (Bayliss and Millhorn, 1992). The factors contributing to the post-hypoxia apneas are not yet clear and require further investigation.

E2 initiates both genomic (Murdoch et al., 1990; Tsai and O’Malley, 1994; Metzger et al., 1995; Lee and Gorski, 1996; McEwen and Alves, 1999) and nongenomic (McEwen and Alves, 
1999; Balthazart and Ball, 2006; Srivastava et al., 2011; Bean et al., 2014; Frick, 2015) signaling. The "canonical" genomic or transcriptional effects of E2 result from activation of the DNA-bound nuclear E2 receptors ER $\alpha$ (Toft and Gorski, 1966; Jensen and Jordan, 2003) and ER $\beta$ (Kuiper et al., 1996). Hormone binding to cytosolic and/or plasma membrane-localized nongenomic ERs activates intracellular signaling pathways that tend to be more rapid in their onset (i.e., within $1 \mathrm{~h}$; Briz et al., 2015) relative to canonical genomic pathways (many hours to days; Scharfman and MacLusky, 2006). Indeed, non-nuclear ER $\alpha$ and ER $\beta$ immunostaining, as well as the G-protein-coupled ER GPR30 (or GPER1; Revankar et al., 2005; Thomas et al., 2005), has been identified in multiple CNS cell types (Milner et al., 2001, 2005; Behan and Thomas, 2005; Olde and Leeb-Lundberg, 2009; Mitterling et al., 2010; Frick, 2015). In other forms of CNS plasticity, membrane-associated ERs can affect a number of cellular pathways (Sellers et al., 2015), including protein translation (Sarkar et al., 2010) and synaptic receptor function (McEwen and Woolley, 1994; Woolley, 2007).

Our data implicate a spinal role for rapid E2 actions in restoring pLTF in OVX rats based on intrathecal application of E2-BSA to the region of the phrenic motor nucleus. This method of localized drug application is well documented (Evrard and Balthazart, 2004; Dougherty et al., 2015; Fields et al., 2015; Huxtable et al., 2015; Nichols et al., 2015; Fields and Mitchell, 2017; AgostoMarlin et al., 2017), and E2-BSA is frequently used to tease out membrane versus nuclear ER activation (Stevis et al., 1999; Fernandez et al., 2008; Wu et al., 2011; Zhang et al., 2012; Sellers et al., 2015). Given that E2-BSA could so rapidly recapitulate the effects of systemically delivered E2 in OVX rats suggests that nongenomic signaling from membrane ERs at the level of the phrenic motor nucleus plays a role in restoration of aIH-induced plasticity, although we do not yet know the specific cell type targeted by estrogen, nor the identity of the ERs responsible. BDNF and serotonin (5HT) neuromodulatory circuits are necessary for pLTF expression (Fuller et al., 2001; Baker-Herman and Mitchell, 2002; Behan et al., 2002, 2003; Baker-Herman et al., 2004; MacFarlane and Mitchell, 2009), and estrogen has many established transcriptional effects on these pathways, including increasing BDNF (Sohrabji et al., 1995) and 5HT synthesis (Hiroi et al., 2006), and/or 5HT receptor density (Biegon and McEwen, 1982; Sumner and Fink, 1998). However, the short time domains of both systemic E2 and intrathecal E2-BSA effects on pLTF expression in our studies argue against these transcriptional mechanisms, and suggest a much faster cascade of effects, perhaps involving altered glutamatergic receptor signaling necessary for pLTF (McGuire et al., 2008). Membrane ER signaling can modulate existing postsynaptic NMDA receptors (Snyder et al., 2011; Zhang et al., 2012) and/or recruit them to active postsynaptic densities (Adams et al., 2004; Smith and McMahon, 2005; Snyder et al., 2011; Potier et al., 2016; Smith et al., 2016). These actions may explain the enhanced phrenic nerve burst response observed during hypoxia with acute E2-BSA treatment, and the corresponding return of pLTF (McGuire et al., 2008). Nongenomic ERs can also enhance ERK/MAPK signaling (Fernandez et al., 2008; Frick, 2009; Zadran et al., 2009; Fan et al., 2010; Wu et al., 2011; Hasegawa et al., 2015; Smith et al., 2016), a pathway necessary for normal pLTF expression in male rats (Hoffman et al., 2012).

Our data unveil a novel and significant role for ovarian hormones, and rapid ER signaling in particular, in the expression of aIH-induced pLTF in young female rats. The present report sets the stage for future mechanistic studies aimed at understanding the effects of sex steroids on multiple levels of the respiratory motor control system. Elucidation of how gonadal steroids modulate respiratory plasticity is fundamental to future translational application of aIH-induced motor plasticity. We suggest that selective modulation of ER-dependent signaling pathways may represent novel targets that can be harnessed to enhance respiratory neuroplasticity in both sexes during periods of respiratory insufficiency resulting from injury or neurodegenerative disease (Mitchell, 2007; Dale et al., 2014; Navarrete-Opazo and Mitchell, 2014; Gonzalez-Rothi et al., 2015).

\section{References}

Adams MM, Fink SE, Janssen WG, Shah RA, Morrison JH (2004) Estrogen modulates synaptic $\mathrm{N}$-methyl-D-aspartate receptor subunit distribution in the aged hippocampus. J Comp Neurol 474:419-426. CrossRef Medline

Agosto-Marlin IM, Nichols NL, Mitchell GS (2017) Adenosine-dependent phrenic motor facilitation is inflammation resistant. J Neurophysiol 117: 836-845. CrossRef Medline

Arevalo MA, Azcoitia I, Gonzalez-Burgos I, Garcia-Segura LM (2015) Signaling mechanisms mediating the regulation of synaptic plasticity and memory by estradiol. Horm Behav 74:19-27. CrossRef Medline

Bach KB, Mitchell GS (1996) Hypoxia-induced long-term facilitation of respiratory activity is serotonin dependent. Respir Physiol 104:251-260. CrossRef Medline

Baker TL, Mitchell GS (2000) Episodic but not continuous hypoxia elicits long-term facilitation of phrenic motor output in rats. J Physiol 529:215219. CrossRef Medline

Baker-Herman TL, Mitchell GS (2002) Phrenic long-term facilitation requires spinal serotonin receptor activation and protein synthesis. J Neurosci 22:6239-6246. Medline

Baker-Herman TL, Fuller DD, Bavis RW, Zabka AG, Golder FJ, Doperalski NJ, Johnson RA, Watters JJ, Mitchell GS (2004) BDNF is necessary and sufficient for spinal respiratory plasticity following intermittent hypoxia. Nat Neurosci 7:48-55. CrossRef Medline

Balthazart J, Ball GF (2006) Is brain estradiol a hormone or a neurotransmitter? Trends Neurosci 29:241-249. CrossRef Medline

Baudry M, Bi X, Aguirre C (2013) Progesterone-estrogen interactions in synaptic plasticity and neuroprotection. Neuroscience 239:280-294. CrossRef Medline

Bayliss DA, Millhorn DE (1992) Central neural mechanisms of progesterone action: application to the respiratory system. J Appl Physiol 73:393404. Medline

Bean LA, Ianov L, Foster TC (2014) Estrogen receptors, the hippocampus, and memory. Neuroscientist 20:534-545. CrossRef Medline

Behan M, Thomas CF (2005) Sex hormone receptors are expressed in identified respiratory motoneurons in male and female rats. Neuroscience 130:725-734. CrossRef Medline

Behan M, Zabka AG, Mitchell GS (2002) Age and gender effects on serotonin-dependent plasticity in respiratory motor control. Respir Physiol Neurobiol 131:65-77. CrossRef Medline

Behan M, Zabka AG, Thomas CF, Mitchell GS (2003) Sex steroid hormones and the neural control of breathing. Respir Physiol Neurobiol 136:249 263. CrossRef Medline

Bi R, Foy MR, Vouimba RM, Thompson RF, Baudry M (2001) Cyclic changes in estradiol regulate synaptic plasticity through the MAP kinase pathway. Proc Natl Acad Sci U S A 98:13391-13395. CrossRef Medline

Biegon A, McEwen BS (1982) Modulation by estradiol of serotonin receptors in brain. J Neurosci 2:199-205. Medline

Briz V, Liu Y, Zhu G, Bi X, Baudry M (2015) A novel form of synaptic plasticity in field CA3 of hippocampus requires GPER1 activation and BDNF release. J Cell Biol 210:1225-1237. CrossRef Medline

Cooke BM, Woolley CS (2005) Gonadal hormone modulation of dendrites in the mammalian CNS. J Neurobiol 64:34-46. CrossRef Medline

Córdoba Montoya DA, Carrer HF (1997) Estrogen facilitates induction of long term potentiation in the hippocampus of awake rats. Brain Res 778: 430-438. CrossRef Medline

Czyzyk A, Casarosa E, Luisi M, Podfigurna-Stopa A, Meczekalski B, Genazzani AR (2014) Brain-derived neurotrophic factor plasma levels in pa- 
tients with Turner syndrome. Gynecol Endocrinol 30:245-249. CrossRef Medline

Dale EA, Ben Mabrouk F, Mitchell GS (2014) Unexpected benefits of intermittent hypoxia: enhanced respiratory and nonrespiratory motor function. Physiology 29:39-48. CrossRef Medline

Dale-Nagle EA, Hoffman MS, MacFarlane PM, Mitchell GS (2010) Multiple pathways to long-lasting phrenic motor facilitation. Adv Exp Med Biol 669:225-230. CrossRef Medline

Darnaudéry M, Perez-Martin M, Del Favero F, Gomez-Roldan C, GarciaSegura LM, Maccari S (2007) Early motherhood in rats is associated with a modification of hippocampal function. Psychoneuroendocrinology 32:803-812. CrossRef Medline

Dempsey JA, Olson EB, Skatrud JB (1986) Hormones and neurochemicals in the regulation of breathing. In: Handbook of physiology, vol. II (Cherniack NS, Widdicombe JG, eds), pp 181-221. Washington, DC: American Physiological Society.

Devinney MJ, Huxtable AG, Nichols NL, Mitchell GS (2013) Hypoxiainduced phrenic long-term facilitation: emergent properties. Ann N Y Acad Sci 1279:143-153. CrossRef Medline

Doperalski NJ, Sandhu MS, Bavis RW, Reier PJ, Fuller DD (2008) Ventilation and phrenic output following high cervical spinal hemisection in male vs female rats. Respir Physiol Neurobiol 162:160-167. CrossRef Medline

Dougherty BJ, Fields DP, Mitchell GS (2015) Mammalian target of rapamycin is required for phrenic long-term facilitation following severe but not moderate acute intermittent hypoxia. J Neurophysiol 114:1784-1791. CrossRef Medline

Evrard HC, Balthazart J (2004) Rapid regulation of pain by estrogens synthesized in spinal dorsal horn neurons. J Neurosci 24:7225-7229. CrossRef Medline

Fan L, Zhao Z, Orr PT, Chambers CH, Lewis MC, Frick KM (2010) Estradiol-induced object memory consolidation in middle-aged female mice requires dorsal hippocampal extracellular signal-regulated kinase and phosphatidylinositol 3-kinase activation. J Neurosci 30:4390-4400. CrossRef Medline

Fernandez SM, Lewis MC, Pechenino AS, Harburger LL, Orr PT, Gresack JE, Schafe GE, Frick KM (2008) Estradiol-induced enhancement of object memory consolidation involves hippocampal extracellular signal-regulated kinase activation and membrane-bound estrogen receptors. J Neurosci 28:8660-8667. CrossRef Medline

Fester L, Rune GM (2015) Sexual neurosteroids and synaptic plasticity in the hippocampus. Brain Res 1621:162-169. CrossRef Medline

Fields DP, Mitchell GS (2017) Divergent cAMP signaling differentially regulates serotonin-induced spinal motor plasticity. Neuropharmacology 113:82-88. CrossRef Medline

Fields DP, Springborn SR, Mitchell GS (2015) Spinal 5-HT7 receptors induce phrenic motor facilitation via EPAC-mTORC1 signaling. J Neurophysiol 114:2015-2022. CrossRef Medline

Foy MR, Xu J, Xie X, Brinton RD, Thompson RF, Berger TW (1999) 17betaestradiol enhances NMDA receptor-mediated EPSPs and long-term potentiation. J Neurophysiol 81:925-929. Medline

Frick KM (2009) Estrogens and age-related memory decline in rodents: what have we learned and where do we go from here? Horm Behav 55:2-23. CrossRef Medline

Frick KM (2015) Molecular mechanisms underlying the memory-enhancing effects of estradiol. Horm Behav 74:4-18. CrossRef Medline

Fuller DD, Mitchell GS (2017) Respiratory neuroplasticity-overview, significance and future directions. Exp Neurol 287:144-152. CrossRef Medline

Fuller DD, Zabka AG, Baker TL, Mitchell GS (2001) Phrenic long-term facilitation requires 5-HT receptor activation during but not following episodic hypoxia. J Appl Physiol 90:2001-2006; discussion 2000. Medline

Galea LA, Leuner B, Slattery DA (2014) Hippocampal plasticity during the peripartum period: influence of sex steroids, stress and ageing. J neuroendocrinol 26:641-648. CrossRef Medline

Gonzalez-Rothi EJ, Lee KZ, Dale EA, Reier PJ, Mitchell GS, Fuller DD (2015) Intermittent hypoxia and neurorehabilitation. J Appl Physiol 119:14551465. CrossRef Medline

Grota LJ, Eik-Nes KB (1967) Plasma progesterone concentrations during pregnancy and lactation in the rat. J Reprod Fertil 13:83-91. CrossRef Medline

Hasegawa Y, Hojo Y, Kojima H, Ikeda M, Hotta K, Sato R, Ooishi Y, Yoshiya
M, Chung BC, Yamazaki T, Kawato S (2015) Estradiol rapidly modulates synaptic plasticity of hippocampal neurons: involvement of kinase networks. Brain Res 1621:147-161. CrossRef Medline

Hayashi F, Coles SK, Bach KB, Mitchell GS, McCrimmon DR (1993) Timedependent phrenic nerve responses to carotid afferent activation: intact vs decerebellate rats. Am J Physiol 265:R811-R819. Medline

Hayes HB, Jayaraman A, Herrmann M, Mitchell GS, Rymer WZ, Trumbower RD (2014) Daily intermittent hypoxia enhances walking after chronic spinal cord injury: a randomized trial. Neurology 82:104-113. CrossRef Medline

Hiroi R, McDevitt RA, Neumaier JF (2006) Estrogen selectively increases tryptophan hydroxylase-2 mRNA expression in distinct subregions of rat midbrain raphe nucleus: association between gene expression and anxiety behavior in the open field. Biol Psychiatry 60:288-295. CrossRef Medline

Hoffman MS, Nichols NL, Macfarlane PM, Mitchell GS (2012) Phrenic long-term facilitation after acute intermittent hypoxia requires spinal ERK activation but not TrkB synthesis. J Appl Physiol 113:1184-1193. CrossRef Medline

Huxtable AG, Smith SM, Peterson TJ, Watters JJ, Mitchell GS (2015) Intermittent hypoxia-induced spinal inflammation impairs respiratory motor plasticity by a spinal p38 MAP kinase-dependent mechanism. J Neurosci 35:6871-6880. CrossRef Medline

Jensen EV, Jordan VC (2003) The estrogen receptor: a model for molecular medicine. Clin Cancer Res 9:1980-1989. Medline

Kimura H, Tatsumi K, Kuriyama T, Sugita T, Watanabe S, Nishibayashi Y, Honda Y (1986) Effect of chlormadinone acetate, a synthetic progesterone, on restoring impaired load compensation in chronic obstructive pulmonary disease. Tohoku J Exp Med 149:119-132. CrossRef Medline

Kimura H, Tatsumi K, Kunitomo F, Okita S, Tojima H, Kouchiyama S, Masuyama S, Shinozaki T, Mikami M, Watanabe S, et al. (1988) Obese patients with sleep apnea syndrome treated by progesterone. Tohoku J Exp Med 156 [Suppl]:151-157. Medline

Knobil E, Neill JD (1994) The physiology of reproduction. New York: Raven.

Kuiper GG, Enmark E, Pelto-Huikko M, Nilsson S, Gustafsson JA (1996) Cloning of a novel receptor expressed in rat prostate and ovary. Proc Natl Acad Sci U S A 93:5925-5930. CrossRef Medline

Lee KZ, Qiu K, Sandhu MS, Elmallah MK, Falk DJ, Lane MA, Reier PJ, Byrne BJ, Fuller DD (2011) Hypoglossal neuropathology and respiratory activity in pompe mice. Front Physiol 2:31. CrossRef Medline

Lee YJ, Gorski J (1996) Estrogen-induced transcription of the progesterone receptor gene does not parallel estrogen receptor occupancy. Proc Natl Acad Sci U S A 93:15180-15184. CrossRef Medline

LévyF, Gheusi G, Keller M (2011) Plasticity of the parental brain: a case for neurogenesis. J Neuroendocrinol 23:984-993. CrossRef Medline

Lynch M, Duffell L, Sandhu M, Srivatsan S, Deatsch K, Kessler A, Mitchell GS, Jayaraman A, Rymer WZ (2017) Effect of acute intermittent hypoxia on motor function in individuals with chronic spinal cord injury following ibuprofen pretreatment: a pilot study. J Spinal Cord Med 40:295-303. CrossRef Medline

MacFarlane PM, Mitchell GS (2009) Episodic spinal serotonin receptor activation elicits long-lasting phrenic motor facilitation by an NADPH oxidase-dependent mechanism. J Physiol 587:5469-5481. CrossRef Medline

Marcondes FK, Bianchi FJ, Tanno AP (2002) Determination of the estrous cycle phases of rats: some helpful considerations. Braz J Biol 62:609-614. CrossRef Medline

McEwen BS, Alves SE (1999) Estrogen actions in the central nervous system. Endocr Rev 20:279-307. CrossRef Medline

McEwen BS, Woolley CS (1994) Estradiol and progesterone regulate neuronal structure and synaptic connectivity in adult as well as developing brain. Exp Gerontol 29:431-436. CrossRef Medline

McEwen BS, Coirini H, Westlind-Danielsson A, Frankfurt M, Gould E, Schumacher M, Woolley C (1991) Steroid hormones as mediators of neural plasticity. J Steroid Biochem Mol Biol 39:223-232. CrossRef Medline

McGuire M, Liu C, Cao Y, Ling L (2008) Formation and maintenance of ventilatory long-term facilitation require NMDA but not non-NMDA receptors in awake rats. J Appl Physiol 105:942-950. CrossRef Medline

Metzger D, Berry M, Ali S, Chambon P (1995) Effect of antagonists on DNA binding properties of the human estrogen receptor in vitro and in vivo. Mol Endocrinol 9:579-591. CrossRef Medline

Milner TA, McEwen BS, Hayashi S, Li CJ, Reagan LP, Alves SE (2001) Ul- 
trastructural evidence that hippocampal alpha estrogen receptors are located at extranuclear sites. J Comp Neurol 429:355-371. CrossRef Medline

Milner TA, Ayoola K, Drake CT, Herrick SP, Tabori NE, McEwen BS, Warrier S, Alves SE (2005) Ultrastructural localization of estrogen receptor beta immunoreactivity in the rat hippocampal formation. J Comp Neurol 491:81-95. CrossRef Medline

Mitchell GS (2007) Respiratory plasticity following intermittent hypoxia: a guide for novel therapeutic approaches to ventilatory control disorders. In: Genetic basis for respiratory control disorders (Gaultier C, ed). New York: Springer.

Mitchell GS, Johnson SM (2003) Neuroplasticity in respiratory motor control. J Appl Physiol 94:358-374. CrossRef Medline

Mitterling KL, Spencer JL, Dziedzic N, Shenoy S, McCarthy K, Waters EM, McEwen BS, Milner TA (2010) Cellular and subcellular localization of estrogen and progestin receptor immunoreactivities in the mouse hippocampus. J Comp Neurol 518:2729-2743. CrossRef Medline

Morishige WK, Pepe GJ, Rothchild I (1973) Serum luteinizing hormone, prolactin and progesterone levels during pregnancy in the rat. Endocrinology 92:1527-1530. CrossRef Medline

Murdoch FE, Meier DA, Furlow JD, Grunwald KA, Gorski J (1990) Estrogen receptor binding to a DNA response element in vitro is not dependent upon estradiol. Biochemistry 29:8377-8385. CrossRef Medline

Nag S, Mokha SS (2014) Activation of a Gq-coupled membrane estrogen receptor rapidly attenuates alpha2-adrenoceptor-induced antinociception via an ERK I/II-dependent, non-genomic mechanism in the female rat. Neuroscience 267:122-134. CrossRef Medline

Navarrete-Opazo A, Mitchell GS (2014) Therapeutic potential of intermittent hypoxia: a matter of dose. Am J Physiol Regul Integr Comp Physiol 307:R1181-R1197. CrossRef Medline

Navarrete-Opazo A, Alcayaga J, Testa D, Quinteros AL (2016) Intermittent hypoxia does not elicit memory impairment in spinal cord injury patients. Arch Clin Neuropsychol 31:332-342. CrossRef Medline

Navarrete-Opazo A, Alcayaga J, Sepúlveda O, Rojas E, Astudillo C (2017) Repetitive intermittent hypoxia and locomotor training enhances walking function in incomplete spinal cord injury subjects: a randomized, triple-blind, placebo-controlled clinical trial. J Neurotrauma 34:18031812. CrossRef Medline

Nichols NL, Satriotomo I, Harrigan DJ, Mitchell GS (2015) Acute intermittent hypoxia induced phrenic long-term facilitation despite increased SOD1 expression in a rat model of ALS. Exp Neurol 273:138-150. CrossRef Medline

Olde B, Leeb-Lundberg LM (2009) GPR30/GPER1: searching for a role in estrogen physiology. Trends Endocrinol Metab 20:409-416. CrossRef Medline

Pappas TC, Gametchu B, Watson CS (1995) Membrane estrogen receptors identified by multiple antibody labeling and impeded-ligand binding. FASEB J 9:404-410. Medline

Pepe GJ, Rothchild I (1974) A comparative study of serum progesterone levels in pregnancy and in various types of pseudopregnancy in the rat. Endocrinology 95:275-279. CrossRef Medline

Pietras RJ, Szego CM (1977) Specific binding sites for oestrogen at the outer surfaces of isolated endometrial cells. Nature 265:69-72. CrossRef Medline

Potier M, Georges F, Brayda-Bruno L, Ladépêche L, Lamothe V, Al Abed AS, Groc L, Marighetto A (2016) Temporal memory and its enhancement by estradiol requires surface dynamics of hippocampal CA1 N-methyl-Daspartate receptors. Biol Psychiatry 79:735-745. CrossRef Medline

Revankar CM, Cimino DF, Sklar LA, Arterburn JB, Prossnitz ER (2005) A transmembrane intracellular estrogen receptor mediates rapid cell signaling. Science 307:1625-1630. CrossRef Medline

Romeo RD, Waters EM, McEwen BS (2004) Steroid-induced hippocampal synaptic plasticity: sex differences and similarities. Neuron Glia Biol 1:219-229. CrossRef Medline

Rosenblatt JS, Mayer AD, Giordano AL (1988) Hormonal basis during pregnancy for the onset of maternal behavior in the rat. Psychoneuroendocrinology 13:29-46. CrossRef Medline

Sarkar SN, Smith LT, Logan SM, Simpkins JW (2010) Estrogen-induced activation of extracellular signal-regulated kinase signaling triggers dendritic resident mRNA translation. Neuroscience 170:1080-1085. CrossRef Medline
Scharfman HE, MacLusky NJ (2006) Estrogen and brain-derived neurotrophic factor (BDNF) in hippocampus: complexity of steroid hormone-growth factor interactions in the adult CNS. Front Neuroendocrinol 27:415-435. CrossRef Medline

Sellers K, Raval P, Srivastava DP (2015) Molecular signature of rapid estrogen regulation of synaptic connectivity and cognition. Front Neuroendocrinol 36:72-89. CrossRef Medline

Skucas VA, Duffy AM, Harte-Hargrove LC, Magagna-Poveda A, Radman T, Chakraborty G, Schroeder CE, MacLusky NJ, Scharfman HE (2013) Testosterone depletion in adult male rats increases mossy fiber transmission, LTP, and sprouting in area CA3 of hippocampus. J Neurosci 33: 2338-2355. CrossRef Medline

Smith CC, McMahon LL (2005) Estrogen-induced increase in the magnitude of long-term potentiation occurs only when the ratio of NMDA transmission to AMPA transmission is increased. J Neurosci 25:7780-7791. CrossRef Medline

Smith CC, McMahon LL (2006) Estradiol-induced increase in the magnitude of long-term potentiation is prevented by blocking NR2Bcontaining receptors. J Neurosci 26:8517-8522. CrossRef Medline

Smith CC, Vedder LC, McMahon LL (2009) Estradiol and the relationship between dendritic spines, NR2B containing NMDA receptors, and the magnitude of long-term potentiation at hippocampal CA3-CA1 synapses. Psychoneuroendocrinology 34 [Suppl 1]:S130-S142. CrossRef Medline

Smith CC, Smith LA, Bredemann TM, McMahon LL (2016) 17beta estradiol recruits GluN2B-containing NMDARs and ERK during induction of long-term potentiation at temporoammonic-CA1 synapses. Hippocampus 26:110-117. CrossRef Medline

Smith MS, Freeman ME, Neill JD (1975) The control of progesterone secretion during the estrous cycle and early pseudopregnancy in the rat: prolactin, gonadotropin and steroid levels associated with rescue of the corpus luteum of pseudopregnancy. Endocrinology 96:219-226. CrossRef Medline

Snyder MA, Cooke BM, Woolley CS (2011) Estradiol potentiation of NR2B-dependent EPSCs is not due to changes in NR2B protein expression or phosphorylation. Hippocampus 21:398-408. CrossRef Medline

Sohrabji F, Miranda RC, Toran-Allerand CD (1995) Identification of a putative estrogen response element in the gene encoding brain-derived neurotrophic factor. Proc Natl Acad Sci U S A 92:11110-11114. CrossRef Medline

Spencer JL, Waters EM, Romeo RD, Wood GE, Milner TA, McEwen BS (2008) Uncovering the mechanisms of estrogen effects on hippocampal function. Front Neuroendocrinol 29:219-237. CrossRef Medline

Srivastava DP, Waters EM, Mermelstein PG, Kramár EA, Shors TJ, Liu F (2011) Rapid estrogen signaling in the brain: implications for the finetuning of neuronal circuitry. J Neurosci 31:16056-16063. CrossRef Medline

Stevis PE, Deecher DC, Suhadolnik L, Mallis LM, Frail DE (1999) Differential effects of estradiol and estradiol-BSA conjugates. Endocrinology 140: 5455-5458. CrossRef Medline

Sumner BE, Fink G (1998) Testosterone as well as estrogen increases serotonin2A receptor mRNA and binding site densities in the male rat brain. Brain Res Mol Brain Res 59:205-214. CrossRef Medline

Tatsumi K, Pickett CK, Jacoby CR, Weil JV, Moore LG (1997) Role of endogenous female hormones in hypoxic chemosensitivity. J Appl Physiol 83:1706-1710. Medline

Thomas P, Pang Y, Filardo EJ, Dong J (2005) Identity of an estrogen membrane receptor coupled to a $G$ protein in human breast cancer cells. Endocrinology 146:624-632. CrossRef Medline

Toft D, Gorski J (1966) A receptor molecule for estrogens: isolation from the rat uterus and preliminary characterization. Proc Natl Acad Sci U S A 55:1574-1581. CrossRef Medline

Trumbower RD, Jayaraman A, Mitchell GS, Rymer WZ (2012) Exposure to acute intermittent hypoxia augments somatic motor function in humans with incomplete spinal cord injury. Neurorehabil Neural Repair 26:163172. CrossRef Medline

Tsai MJ, O’Malley BW (1994) Molecular mechanisms of action of steroid/ thyroid receptor superfamily members. Annu Rev Biochem 63:451-486. CrossRef Medline

Woolley CS (2007) Acute effects of estrogen on neuronal physiology. Annu Rev Pharmacol Toxicol 47:657-680. CrossRef Medline

Wu TW, Chen S, Brinton RD (2011) Membrane estrogen receptors mediate 
calcium signaling and MAP kinase activation in individual hippocampal neurons. Brain Res 1379:34-43. CrossRef Medline

Zabka AG, Behan M, Mitchell GS (2001) Selected contribution: timedependent hypoxic respiratory responses in female rats are influenced by age and by the estrus cycle. J Appl Physiol (1985) 91:2831-2838. Medline

Zabka AG, Mitchell GS, Olson EB Jr, Behan M (2003) Selected contribution: chronic intermittent hypoxia enhances respiratory long-term facilitation in geriatric female rats. J Appl Physiol (1985) 95:2614-2623; discussion 2604. Medline

Zabka AG, Mitchell GS, Behan M (2005) Ageing and gonadectomy have similar effects on hypoglossal long-term facilitation in male Fischer rats. J Physiol 563:557-568. CrossRef Medline

Zabka AG, Mitchell GS, Behan M (2006) Conversion from testosterone to oestradiol is required to modulate respiratory long-term facilitation in male rats. J Physiol 576:903-912. CrossRef Medline

Zadran S, Qin Q, Bi X, Zadran H, Kim Y, Foy MR, Thompson R, Baudry M (2009) 17-Beta-estradiol increases neuronal excitability through MAP kinase-induced calpain activation. Proc Natl Acad Sci U S A 106:2193621941. CrossRef Medline

Zhang Y, Xiao X, Zhang XM, Zhao ZQ, Zhang YQ (2012) Estrogen facilitates spinal cord synaptic transmission via membrane-bound estrogen receptors: implications for pain hypersensitivity. J Biol Chem 287:33268 33281. CrossRef Medline

Zhou Y, Watters JJ, Dorsa DM (1996) Estrogen rapidly induces the phosphorylation of the cAMP response element binding protein in rat brain. Endocrinology 137:2163-2166. CrossRef Medline 